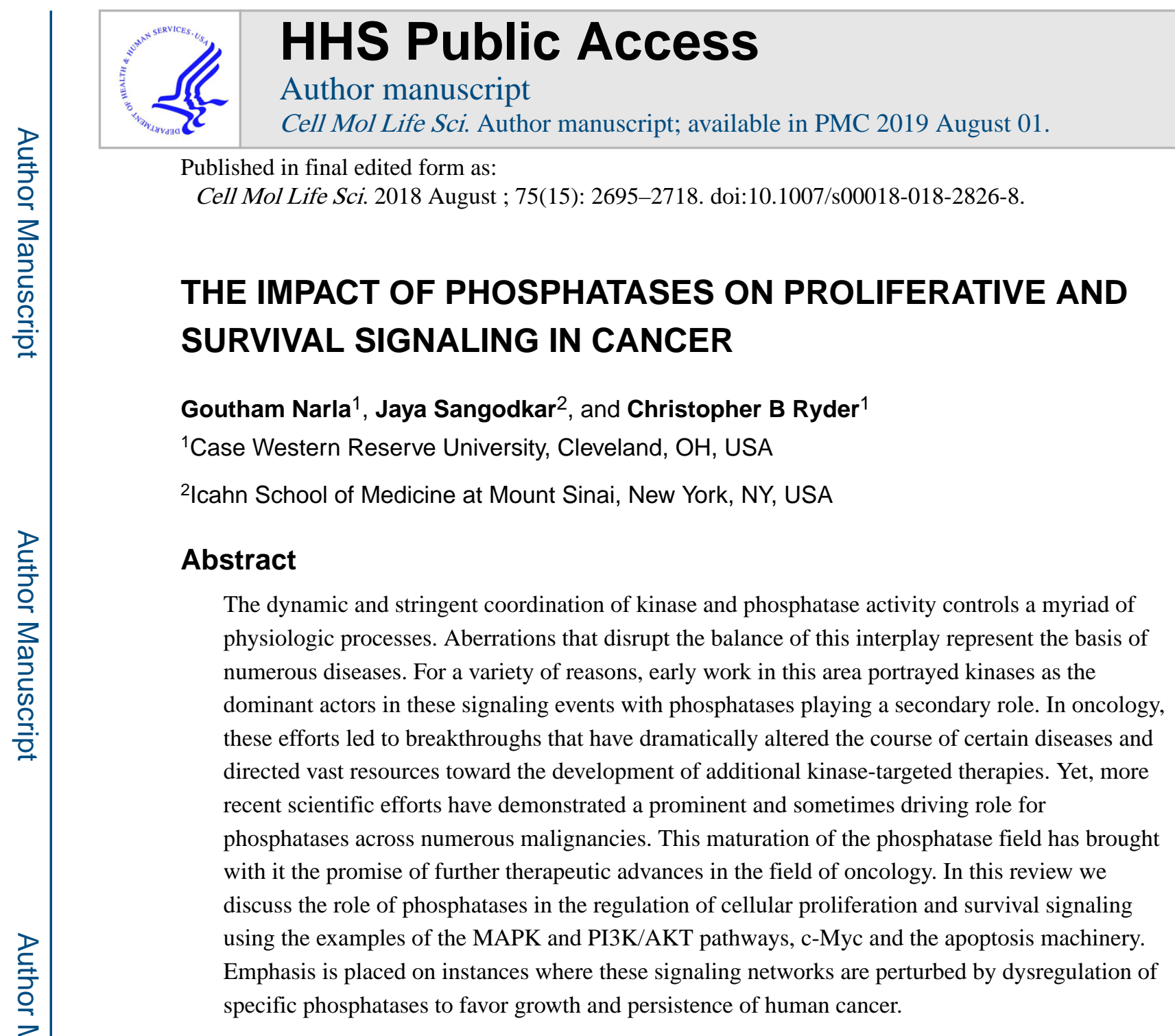

\title{
Introduction
}

Physiologic signaling relies on the coordinated transduction of messages in a manner that is tightly regulated both in space and time. Thus, the propagation of a signal within the cytoplasmic compartment can have different effects from the same message being transmitted to the nucleus. Likewise, the activation of a signaling cascade in a pulsatile or oscillatory pattern can have divergent phenotypic consequences compared to sustained activity of the same pathway [1]. Among the many mediators of cellular signaling, an immense literature has accumulated about the role of reversible phosphorylation of proteins and other biomolecules in these processes. The opposing actions of kinases and phosphatases act to toggle the activity of biological processes from the "on" to the "off" state in response to upstream stimuli. Moreover, proteins often harbor multiple phosphorylation sites, thereby allowing them to serve as integration nodes for multiple input signals. While the sophistication displayed by this form of cellular communication is both intricate and elegant, it also creates opportunity for dysregulation at a number of steps along 
the path from stimulus to biologic output. Such derangements represent the pathophysiologic basis of many disease states.

As major signaling nodes for both extracellular and intracellular stimuli, kinases affect numerous processes that determine cell fate including growth, replication, survival and death. It should, therefore, be of no surprise that many kinases have been identified as drivers of tumorigenesis. In addition to helping to explain the evolution of some cancers, these discoveries have led to novel treatments for patients and have dramatically altered the outlook for several malignancies [2]. Frequently, the targets of these kinases require tight regulation in order to maintain cellular homeostasis. In normal physiology it is the action of phosphatases that opposes kinases to stop or restart a signal or to maintain readiness for future stimuli. Therefore, alterations involving either kinases, phosphatases or both in combination can disrupt this requisite balance in favor of proliferation and survival. It has become increasingly apparent that the balance between kinase and phosphatase activity is tipped in favor of oncogenic signaling outputs across cancer types [3,2]. While our understanding of the contribution of phosphatase signaling to cancer has not yet contributed ammunition to the oncology armamentarium, immense progress has been made toward that end since the first identification of a phosphatase as a tumor suppressor two decades ago $[4,5]$. In fact, phosphatase modifying agents have advanced to clinical trials in cancer and may provide clinical benefit in the near future [6]. As such, it is essential to maximize our understanding of the contribution of phosphatases to the oncogenic process in order to develop novel therapeutic strategies and to optimize current approaches to targeting these enzymes in cancer.

Phosphatases are categorized according to the amino acids or other molecules that they modify and subcategorized by mechanism of action. Focusing on protein phosphatases, such ontological endeavors give us two major categories: the highly diverse protein tyrosine (Tyr) phosphatases (PTPs) and the protein serine/threonine (Ser/Thr) phosphatases (PSPs; see Figure 1 and Table 1). Analysis of the contribution of each to the overall phospho-proteome has revealed that over $98 \%$ of all protein phosphorylation events occur on Ser/Thr residues [7], which makes sense as these modifications often serve to amplify upstream signals. The downstream position of these post-translational modifications (PTMs) places them in close proximity to the final effectors of phenotype, whereas PTPs generally control upstream signals. As a testament to the critical role of both PTPs and PSPs in disease, both families have been the subject of significant drug discovery efforts [8,9]. The goal of this review is to highlight the contribution of phosphatases to the regulation of several major signaling pathways that control cancer cell proliferation and survival.

\section{Introduction to Phosphatases}

\section{Protein Tyr Phosphatases (PTPs)}

The largest category of phosphatases, the PTP family, contains over 100 members (Reviewed in [10,11]; see Figure 1 and Table 1). "Classical" PTPs with specificity for pTyr alone include nearly 40 members, some being transmembrane-spanning receptor PTPs and others being of the non-receptor type. Additionally included in this family are three classes of dual-specificity phosphatases (DUSPs), which catalyze the removal of phosphate from 
pSer/pThr as well as pTyr. Some of these DUSPs have activity toward phospholipids and other biomolecules instead of or in addition to protein phosphatase activity; this subset includes PTEN (phosphatase and tensin homolog deleted on chromosome 10), perhaps the most-studied phosphatase in the field of oncology. Finally, there are the aspartate(Asp)based and histidine(His)-based PTPs. All but the last two of these groups utilize a cysteine(Cys)-based catalytic site to perform their enzymatic function. PTPs are generally monomeric proteins, with specific domains that determine subcellular localization or perform auto-regulatory functions as well as regions bordering the catalytic site that help to determine substrate specificity.

Importantly, various PTPs demonstrate either inhibitory and/or driving roles in tumorigenesis and tumor persistence. The tumor suppressor PTEN has already been mentioned; additional PTPs exert well-described tumor suppressive functions as well. On the other hand, some PTPs display oncogenic functions in human cancers. For other PTPs, the data is mixed or they exert apparently divergent effects in different tissues or experimental systems. Several PTPs will be discussed in the context of selected pathways that they perturb in cancer. For a more in-depth view of PTPs, interested readers are referred to the following comprehensive reviews $[12,10,13]$.

\section{Protein Ser/Thr Phosphatases (PSPs)}

The other major category of protein phosphatases, PSPs, is grouped into three main familiesthe phosphoprotein phosphatases (PPP), the metal-dependent protein phosphatases (PPM), and the Asp-based phosphatases (FCP/SCP; see Figure 1 and Table 1) [14,12]. These three groups encompass only around 40 distinct catalytic subunits. However, whereas PTPs are generally multi-domain monomeric proteins, some PSPs truly comprise a collection of holoenzymes composed of two or more subunits. For these multimeric PSPs, the diversity of substrate targeting is dramatically increased by their association with different regulatory subunits. For example, while protein phosphatase 2A (PP2A) has only two catalytic isoforms (PP2A-Ca and PP2A-C $\beta$ ), by pairing with its two scaffolding (A) subunits and 15 regulatory (B) subunit genes (producing at least 23 isoforms) more than 90 possible trimeric holoenzymes are possible [14]. Likewise, PP1 describes the complex of its catalytic protein (of which there exist three isoforms) with one of numerous regulatory subunits. Therefore, when considering the function of one of these multimeric PSPs in signaling it is critical to think in terms of the specific holoenzyme involved since each heterotrimer is essentially a unique phosphatase as it relates to localization of activity, target specificity and/or phenotypic effects. This combinatorial diversity may help to explain the ten-fold excess of Ser/Thr kinases over PSPs in the genome compared to the near balance in number between protein Tyr kinases and PTPs. It also makes the study of both catalytic and regulatory subunits important to understanding the functional state of these phosphatases in cancer.

The importance of considering all components of a multimeric PSP in cancer may again be best exemplified by trimeric PP2A. Considerable evidence has accumulated regarding altered expression, deletion and/or mutation of various subunits of this phosphatase as well as expression of its endogenous inhibitors across numerous cancer types (Reviewed in [1416]). Thus, there are many ways in which signaling by this phosphatase are disturbed in 
cancer. The multitude of ways in which PP2A components are dysregulated and the overall prevalence of these perturbations in cancer underscore their importance. Yet this complexity likewise increases the difficulty in studying its contributions to the oncogenic process. The aggregate of data published over the past several decades largely implicates PP2A as a tumor suppressor. Yet, some individual PP2A holoenzymes appear to exert oncogenic functions. To further complicate matters, the cellular context required to enable these divergent functions to become manifest are not yet fully understood. This level of detailed understanding of phosphatase activities in cancer will be necessary to properly translate scientific gains in the field to therapeutic benefit for patients with cancer. Other members of the PSP family exhibit either tumor suppressive and/or oncogenic properties as well. Specific examples will be provided in the following sections.

\section{Introduction to Oncogenic Signaling}

Hannahan and Weinberg heralded in the $21^{\text {st }}$ century of oncology research by outlining the necessary processes that must be coopted for a cancer to develop [17]. This work and its update [18] laid out the framework with which we think about oncogenic signaling today. The original hallmarks of cancer included sustained proliferative signaling, escape from growth suppression, resistance to cell death, and the induction of angiogenesis, invasion/ metastasis and replicative immortality. Cancer-associated genetic alterations trigger signaling aberrations that facilitate the acquisition of one or more of these traits. The work synthesized in the "hallmarks" paper and subsequent advances have revealed a trove of information about the roles of both kinases and phosphatases in cancer development and maintenance. For example, PTEN deletion across many cancers [19], SHP2 (PTPN11) activating mutation in hematologic and other malignancies [20,21], and a variety of perturbations in components of the PP2A machinery $[16,15]$ provide well-established contributions to tumorigenesis in humans. A full consideration of the influences of phosphatases on all relevant oncogenic pathways is beyond the scope of this article. Thus, for this review we have chosen to frame the discussion around several of the major pathways that contribute to proliferative signaling and to the regulation of apoptosis in cancer. Namely, we will discuss the contribution of phosphatase signaling to the regulation of the phosphatidylinositol 3-kinase (PI3K)/AKT and mitogen-activated protein kinase (MAPK) pathways, c-Myc and the apoptotic machinery. Within this context we will provide examples where altered phosphatase function contributes to the oncogenic process in experimental systems and in human disease.

\section{PI3K/AKT}

The PI3K signaling pathway affects many cellular processes including growth, metabolism, proliferation, migration, and apoptosis [22,23]. This kinase directly phosphorylates the lipid molecule phosphatidylinositol-4,5-biphosphate (PIP2) to form phosphatidylinositol-3,4,5triphosphate (PIP3; Figure 2). Subsequently, PIP3 recruits protein kinases such as PDK1 and AKT to the cell membrane by binding to pleckstrin homology $(\mathrm{PH})$ domains that coordinate the protein-lipid interaction [24,25]. One of the major effectors and readouts of activated PI3K signaling is the Ser/Thr kinase AKT, which is activated by phosphorylation at Ser473 by $\mathrm{mTORC} 2$ and at Thr308 by PDK1 (reviewed in $[26,27]$ ). Other kinases can additionally 
phosphorylate AKT. Subsequently, AKT engages several downstream substrates that act as effectors or additional mediators of PI3K signaling. Hyperactivation of this signaling cascade occurs frequently across cancer types, mechanistically through amplification of upstream signals, mutations in oncogenes such as PIK3CA among others [28] and loss of tumor suppressive modulators, including several phosphatases, as reviewed herein.

One important PI3K inhibitory tumor suppressor that has already been alluded to is PTEN, whose canonical function is to dephosphorylate PIP3 [29]. By doing so, PTEN counteracts proliferation and cell survival processes activated by PI3K signaling (Figure 1). Two groups independently identified PTEN as the tumor suppressor gene located on chromosome 10q23 [4,5], a site known for loss of heterozygosity in many human tumors [30]. Deletion or loss of heterozygosity of PTEN occurs in many malignancies including glioma, breast and prostate cancer and hematologic malignancies [19]. Germline mutations in PTENhave also been observed in cancer-predisposing syndromes such as Cowden syndrome and are collectively known as PTEN hamartoma tumor syndromes [19,31]. As such, PTEN acts as a driver mutation in the development of cancer through loss of control over PI3K/AKT signaling. However, recent work has shown that even PTEN can perform oncogenic functions, as its deletion or targeted inhibition in B-cell lymphoblastic leukemia/lymphoma (B-ALL) led to regression of disease and enhanced survival in mouse models [32].

Downstream of PI3K, the AKT signaling pathway is inhibited by the PH domain leucinerich repeat protein phosphatases (PHLPPs), which are part of the PPM subtype of PSPs [33]. PHLPPs were first discovered to dephosphorylate and inactivate AKT directly on its Cterminal Ser473 residue [34]. The two isozymes that comprise PHLPPs are PHLPP1, which modulates AKT2, and PHLPP2, which modulates AKT1 [35]. Other PHLPP substrates include protein kinase $C \beta I I$ [36] and ribosomal protein S6 kinase [37]. Loss or decreased expression of PHLPPs has been observed in tumors of bone, colon and prostate, among others, in line with their tumor suppressive functions [38-43].

Various PP2A holoenzymes regulate the AKT signaling pathway by dephosphorylation at the Thr308 residue, resulting in kinase inactivation [44-48]. The PP2A-B55a regulatory subunit (encoded by PPP2R2A) has been found to directly bind AKT in lymphoid cells [49] whereas the B56 $\beta$ subunit binds to AKT in adipocytes [50]. The PP2AB56 $\gamma$ subunit also has been linked to decreased AKT phosphorylation [51]. For B55a both decreased gene expression and rarely deletion have been shown to occur in acute myeloid leukemia (AML), with the former correlating with reductions in overall survival and increased Thr308 AKT phosphorylation in patients and the latter with sensitivity to AKT-targeted therapy in vitro $[52,49,53]$. Recurrent deletions of $P P P 2 R 2 A$ also occur in breast, prostate and other cancers [54-56].

Thus, both PTPs and PSPs contribute to the regulation of PI3K/AKT signaling and their dysregulation has a direct role in oncogenesis. Surprisingly, even classical tumor suppressors like PTEN can have context-dependent effects. Continued efforts will be necessary to maximize the potential of targeting these derangements for therapeutic benefit and to develop novel biomarkers to guide treatment decisions. 


\section{MAPK signaling}

A second major intracellular proliferative and pro-survival signaling pathway involves the proto-oncogene RAS [57]. Physiologic stimuli activate RAS signaling downstream of receptor Tyr kinases (RTKs) and other cell surface molecules (Figure 2). For RTKs, kinase domain phosphorylation produces binding sites for proteins with SRC homology 2 ( $\mathrm{SH} 2$ ) domains, with growth factor receptor bound protein 2 (GRB2) being one important SH2containing adapter. Binding of GRB2 to an RTK activates the guanine nucleotide exchange factor (GEF) activity of son of sevenless protein (SOS). SOS then promotes RAS to exchange GDP for GTP, thereby producing its active state. Once activated, RAS stimulates several effector proteins such as p120 GTPase activating protein (GAP), RalGDS and other GEFs, as well as a number of protein kinases including: PI3K, protein kinase $\mathrm{C}$ (PKC), cJun $\mathrm{NH}_{2}$ terminal kinase (JNK), mitogen-activated protein kinase kinase kinase (MEKK), mitogen-activated protein kinase kinase (MEK), and extracellular signal-regulated kinases (ERK1/2) [57]. To extinguish the signal, RAS harbors intrinsic GTP hydrolytic activity that is accelerated by GAPs. Different GEFs and GAPs control RAS activation downstream of various other stimuli. The RAS proteins are additionally regulated by PTMs that contribute to subcellular localization and activity [58]. Depending on cellular context as well as pattern, extent and duration of activation, RAS can trigger a wide variety of responses, ranging from cell death to cell growth and propagation. As with the PI3K pathway, activating mutations in RAS pathway genes (KRAS, NRAS, BRAF, etc.) are common in cancer [28].

Phosphatases provide both positive and negative signals to various components of the MAPK pathway. For one, PHLPP1/2 were found to directly dephosphorylate RAF1 at Ser388, a crucial residue for its activation [59]. Thus, these PSPs negatively regulate both the MAPK and PI3K pathways. Conversely, the PTP SHP2 is a proto-oncogene, with activating mutations enhancing RAS-ERK activity and promoting leukemogenesis [20]. Yet, while its cell intrinsic effects are oncogenic SHP2 appears to additionally have tumor suppressive functions in colitis-associated tumorigenesis [60].

Likewise, there is evidence for both activating as well as inhibitory effects of PP2A-B55a on the RAS signaling pathway through RAF1 and ERK, respectively. First, PP2A-B55a positively regulates this pathway by dephosphorylating Ser259, an inhibitory site on RAF1. Additionally, PP2A-B55a dephosphorylates kinase suppressor of RAS (KSR) at Ser392, within a key 14-3-3 binding site. This dephosphorylation results in the displacement of 14-3-3, subsequent membrane recruitment of KSR and activation of downstream signaling [61,62]. Yet, this same holoenzyme has been implicated in the negative regulation of RAS signaling. Downregulation of B55a has been shown to decrease phosphorylation of ERK1/2 in several different cell types including lung adenocarcinoma and pancreatic ductal carcinoma [63,64]. In these latter systems, PP2A-B55a was not tested as an ERK phosphatase and it remains possible that these effects are indirect.

The RAS signaling pathway is also regulated by the MAPK phosphatases (MKPs), which are among the VH1-like DUSPs [65,66]. Individual MKPs recognize and dephosphorylate various MAPKs. MKP-1 (DUSP1) is localized to the nucleus and dephosphorylates ERK, JNK, and p38. MKP-1 has been found to be altered in several cancers [67-74]. In certain 
cancer types, its expression is increased in earlier stages and lowered in later stages of the disease. MKP-2 (DUSP4) is also localized to the nucleus and dephosphorylates ERK, JNK, and $\mathrm{p} 38[75,76]$. Based on context, there is evidence that MKP-2 expression is antitumorigenic in breast, ovarian and non-small cell lung cancers [77-80]. PAC-1 (DUSP2) and hVH3 (DUSP5) also localize to the nucleus. PAC-1 dephosphorylates ERK and p38 while $\mathrm{hVH} 3$ dephosphorylates ERK. PAC-1 is downregulated in several cancers and its overexpression inhibits tumorigenesis; $\mathrm{hVH} 3$ is also downregulated in several cancers [8183]. MKP-3 (DUSP6), MKP-4 (DUSP9), and DUSP7 are localized to the cytoplasm. MKP-3 dephosphorylates ERK and MKP-4 dephosphorylates ERK and p38. MKP-5 (DUSP10), MKP-7 (DUSP16) and hVH5 (DUSP8) are localized to both the nucleus and cytoplasm and they dephosphorylate JNK and p38. Thus, MKPs largely function to attenuate the activity of MAPK effectors.

Other phosphatases implicated in control of MAPK signaling include PP2Ca (PPM1A) and PP2C $\beta$ (PPM1B), which belong to the group of PSPs that require $\mathrm{Mn}^{2+} / \mathrm{Mg}^{2+}$ for their catalytic activity [84-86]. PP2Ca and PP2C $\beta$ regulate the MAPK signaling pathway at multiple levels. PP2Ca inhibits JNK signaling by dephosphorylating its upstream activating kinases MKK4 and MKK7. Both PP2Ca and PP2C $\beta$ inhibit $\mathrm{p} 38$ by dephosphorylation of two of its upstream activators, MKK3b and MKK6b [87]. Additionally, PP2Ca has been found to directly dephosphorylate ERK2 at Thr202, resulting in its inhibition [88]. Both $\mathrm{PP} 2 \mathrm{Ca}$ and $\mathrm{PP} 2 \mathrm{C} \beta$ are decreased in some cancer types and their overexpression imposes tumor suppressive properties [89-92].

As a phosphorylation signaling cascade, MAPK signaling is normally under the control of phosphatases at multiple levels. The evidence provided above demonstrates several ways in which different phosphatases may have either promoting or inhibitory effects on the output of this pathway, though phosphatases largely serve to dampen proliferative and pro-survival MAPK activity. It will be important to further our understanding of the implications of dysregulated phosphatase activity on the spatiotemporal control of this dynamic pathway. Such efforts may give rise to novel means to modulate MAPK signaling output for therapeutic benefit in cancers.

\section{C-Myc}

The transcription factor c-Myc is involved in numerous oncogenic processes, including cell growth, proliferation, metabolism and apoptosis. Expression of the $M Y C$ gene is increased in many cancers by amplification, translocation, and/or mutation. Under normal conditions, both the gene and its protein product are tightly regulated at the transcriptional, translational and post-translational levels (reviewed in [93]). Its transcript is induced by mitogens and translated in response to growth signals, some of which are mediated by the PI3K and MAPK pathways. In order to enable rapid changes in c-Myc activity, both its mRNA and protein have half-lives between 10-30 minutes in normal cells [94,95]. These short lifespans are the result of stringent regulatory mechanisms that serve to restrict unchecked activity of the proto-oncogene. The disruption of these regulatory mechanisms contributes to tumorigenesis. 
At the post-translational level, c-Myc undergoes a series of coordinated phosphorylation/ dephosphorylation events, with intervening proline isomerization (Reviewed in [96]; see Figure 3). Phosphorylation of c-Myc at Ser62 by ERK and/or CDKs enhances its transactivation capacity; proline isomerization by Pin1 contributes to full activation of cMyc [97,98]. The B56a-containing PP2A holoenzyme dephosphorylates pSer62 on c-Myc that has been secondarily phosphorylated on Tyr58 by GSK-3 $\beta$ and that for which Pro63 in the trans position $[99,96]$. This dephosphorylation of pTyr58/pSer62 c-Myc to produce the pTyr58 mono-phosphorylated form facilitates its ubiquitination and degradation by the proteasome.

Interestingly, c-Myc binds to the promoter of PPP2R5D which encodes for PP2A-B566. This transactivation leads to increased Tyr58 phosphorylation of c-Myc via GSK-3 $\beta$ activation [100]. This process should function as a negative feedback loop on c-Myc activity. It is therefore important to note that PPP2R5D knockout mice spontaneously develop hepatocellular carcinomas with c-Myc Ser62 hyperphosphorylation, confirming one mechanism by which deregulated phosphatase signaling promotes Myc-driven tumorigenesis [101].

Recently, the DUSP Eya1 was found to stabilize c-Myc by dephosphorylating pTyr58 [102]. Interestingly, Eya1 appears to have opposing preference compared to PP2A regarding the isomerization state of c-Myc, as Pin1 inhibited the ability of Eya1 to dephosphorylate pTyr58 [103]. This is in contrast to data showing that Pin1 promotes PP2A dephosphorylation of pSer62 [104]. By preventing the degradation of c-Myc, Eyal functions as an oncogene; its PTP activity is also oncogenic (Reviewed in [105]). We await a complete understanding of the coordinated interplay among these various PTMs on c-Myc in normal physiology but it is clear that the deregulation of one or more of these processes can tip the balance toward tumor promotion.

Other evidence suggests additional mechanisms by which PP2A and c-Myc interact with one another in cancer. For example, in colorectal cancer, epigenetic silencing of $P P P 2 R 2 B$ (B55 $\beta$ ) promotes rapamycin resistance in a manner that involves c-Myc activation [106]. Likewise, decreased Axin levels confer increased c-Myc stability in breast cancer by preventing the formation of its destruction complex, which includes PP2A-B56a [107]. Furthermore, B55a and c-Myc show a positive correlation in AML patient samples by reverse phase protein array [52]. As an explanation, knockdown of B55a seems to decrease c-Myc levels due to compensatory increases in the B56a subunit. Another phosphatase, PTPN2, seems to cooperate in Myc-driven B-cell lymphomas as it is commonly overexpressed in this context and promotes proliferation [108]. However, this PTP is also deleted in T-cell malignancies and breast cancer, where its loss enables elevated JAK/STAT signaling [109-112]. It is possible that ectopic c-Myc expression compensates for the inhibition of STAT signaling by PTPN2 [113], allowing for its oncogenic functions to predominate in c-Myc-driven lymphomagenesis.

In addition to its post-translational regulation by phosphorylation, c-Myc regulation also occurs at the level of translation. Its mRNA is short-lived, as previously mentioned, and like several other oncogenes (Mcl-1, Cyclin D1, etc.) its translation is cap-dependent [114]. 
Therefore, constitutive activation of cap-dependent translational machinery can augment cMyc protein translation. Conversely, inhibition of cap-dependent translation can rapidly reduce c-Myc protein abundance. Regulation of cap-dependent translation occurs downstream of both the RAS/ERK and PI3K/AKT pathways, with the former signaling to eIF4E by activating phosphorylation and the latter by inhibitory phosphorylation of 4E-BP1 (Reviewed in [114]). There is in vitro evidence that eIF4E and its upstream kinases MNK1/2 are targets for dephosphorylation by PP2A [115]. The activity of PP2A also serves to reduce 4E-BP1 phosphorylation but this probably occurs indirectly through inhibition of the PI3K/AKT pathway [116]. Another PSP, PPM1G, dephosphorylates 4E-BP1 to inhibit capdependent translation [117]. Interestingly, PPM1G is itself a phosphoprotein that undergoes activating phosphorylation by ATM and inhibitory phosphorylation downstream of PI3K/AKT [118,119]. Thus, loss of ATM and/or increased activity of the PI3K pathway, both of which are common in cancers, will diminish PPM1G activity and promote capdependent translation. PHLPPs, negative feedback regulators of AKT already mentioned above as being lost or depleted in various malignancies, block cap-dependent translation by inhibitory dephosphorylation of S6K1 [37,120]. Thus, the activity of several tumor suppressive phosphatases serves to decrease translation of $M Y C$ and other cap-dependent oncogenes and the loss of such phosphatase activity is relevant to human cancer.

From direct protein dephosphorylation to alter its stability and activity to regulation of pathways that control its synthesis, phosphatases contribute heavily to the tight regulation of c-Myc activity. Furthermore, c-Myc itself drives expression of a negative feedback regulatory B subunit of PP2A. This stringent phosphatase-mediated regulation is lost in many cancers and, moreover, oncogenic phosphatase activity additionally cooperates with cMyc or enhances its function in some cancer types. As c-Myc has proven difficult to target pharmacologically, phosphatase targeting agents have great potential to provide new means to affect this critical oncogene.

\section{The Apoptosis Cascade}

Among the aforementioned hallmarks of cancer is the evasion of apoptosis, an evolutionarily conserved process of programmed cell death. Its two major branches, extrinsic and intrinsic, allow for the activation of this process both by external signaling to death receptors and by altering the rheostat of Bcl-2 family members in response to various cellular stresses (reviewed in $[121,122]$ ). Furthermore, the extrinsic pathway can amplify the activity of the intrinsic pathway, which is necessary for robust apoptosis in some cell types. The extrinsic pathway of apoptosis begins with interaction between a death receptor and its ligand, which activates a signaling cascade to produce the death-inducing signaling complex (DISC); its initial caspase effector is caspase-8. The intrinsic, or mitochondrial, pathway commences with oligomerization of Bax and/or Bak to cause mitochondrial outer membrane permeabilization (MOMP); this pore formation allows for the release of cytochrome $\mathrm{c}$ and other pro-apoptotic factors from the mitochondria. Cytochrome $\mathrm{c}$ pairs with apoptotic peptidase activating factor-1 (APAF-1) and dATP to activate pro-caspase-9, together termed the apoptosome. Whether initiated by caspase- 8 or caspase- 9 , the two apoptotic pathways converge on activation of caspase- 3 and caspase-7 as the final executioners (see Figure 4). 
Though these caspases share some common substrates, they appear to perform distinct roles in the apoptotic process as well [123].

Along with both using the same effector caspases, another shared feature of the two apoptotic pathways is their regulation by Bcl- 2 family members. For the intrinsic pathway, the interplay between these proteins governs the decision to undergo apoptosis; for the extrinsic pathway, the truncation of Bid by caspase- 8 allows for crosstalk with the intrinsic pathway. The apoptosis-governing Bcl-2 proteins share regions of homology that, along with their function in promoting or inhibiting apoptosis, allow them to be separated into three groups: the anti-apoptotic proteins, the Bcl-2 homology 3 (BH3)-only members and the multi-domain pro-apoptotic forms Bax and Bak (reviewed in [124]). The anti-apoptotic Bcl-2 family members function by sequestering their pro-apoptotic homologs. This group includes the founding member Bcl-2, as well as Bcl-A1, Bcl-w, Bcl-xL and Mcl-1. The BH3-only proteins include Bad, Beclin-1, Bid, Bim, Blk, Bmf, Hrk, Noxa, and Puma. This group can be further divided into; 1) direct activators, those proteins that interact directly with Bax and/or Bak to induce their oligomerization in the mitochondrial outer membrane and 2) sensitizers, those members that bind to anti-apoptotic Bcl-2 family members and thereby free up their direct activator homologs to activate Bax/Bak (Figure 4). Other models exist that introduce subtle distinctions about the modes of interaction between Bcl-2 family members in controlling apoptosis based on extensive experimental data [125]. Basically, the stoichiometric ratio between pro- and anti-apoptotic proteins determines cell fate. However, the localization and interaction between Bcl-2 family members is additionally modulated by PTMs. To add an added layer of complexity, several Bcl-2 family members have splice variants with distinct activities to their full-length isoforms and some perform functions in addition to their canonical roles in apoptosis regulation.

While changes in susceptibility of cancer cells to apoptosis have been attributed to knockdown/knockout or overexpression of a number of phosphatases, for this section we will focus on phosphatase activities that directly regulate components of either the intrinsic or extrinsic pathways of apoptosis.

\section{Regulation of the Intrinsic Apoptotic Pathway by Phosphatase Signaling}

It should come as no surprise that phosphorylation controls the activity of apoptosome complex proteins, as apoptosome-mediated caspase activation represents a point of no return. For example, APAF-1 undergoes inhibitory phosphorylation by 90-kDa ribosomal S6 kinase [126]. Additionally, caspase- 9 is heavily phosphorylated, reportedly at 11 sites by as many as nine different kinases [127]. As is a common theme among apoptosis-regulating proteins these phosphorylation events decrease apoptosis induction, although there is one disputed site of supposed pro-apoptotic phosphorylation on caspase-9 (Tyr153) [127,128]. Despite the abundance of literature on phosphorylation of these critical apoptotic mediators, there is a lack of evidence about the regulation of these anti-apoptotic PTMs by phosphatase signaling. Yet, the contribution of phosphatases is likely important. The phosphatase inhibitor okadaic acid (OA) was shown to enhance phosphorylation of Thr125 on caspase-9 [129], while a later report confirmed that PP1a can dephosphorylate this site to promote apoptosis [130]. 
Members of the Bcl-2 family display diverse mechanisms of regulation, with some primarily under transcriptional control and others more tightly controlled at the level of translation or by PTMs including phosphorylation and ubiquitination. These post-translational changes control the stability, subcellular localization and/or binding characteristics of each protein.

Among the pro-apoptotic BH3-only proteins, several have been shown to be regulated by phosphorylation. For example, Noxa phosphorylation by CDK5 inhibits its function by partially masking its BH3 domain [131,132]. Similarly, the BH3-only protein Bmf additionally undergoes anti-apoptotic phosphorylation by ERK2 [133]. In a variation on the theme, phosphorylation of Bim and Puma target them for ubiquitination and subsequent proteasomal degradation $[134,135]$. Conversely, the pro-apoptotic activity of Bik is reportedly enhanced by phosphorylation [136,137]. The counteracting phosphatases for these BH3-only proteins are not yet known. However, a number of phosphatases have been implicated in dephosphorylation of the BH3-only protein Bad, which is phosphorylated downstream of growth factor and other proliferative and survival signals [138]. The implicated phosphatases include PP2A [139], PP2C $\beta$ [140], PP1 [141], and PP2B [142]. While Bad contains a number of phosphorylation sites [143], in all reported cases dephosphorylation promotes mitochondrial localization and/or pro-apoptotic activity.

A multitude of studies have described phosphorylation of anti-apoptotic Bcl-2 in various contexts, much of which indicates that phosphorylation at Ser70 enhances its anti-apoptotic function (Reviewed in [144]). Dephosphorylation of Bcl-2 Ser70 has been shown to reduce its anti-apoptotic function [145,146]. However, competing data shows that expression of a Ser70Asp Bcl-2 phospho-mimetic promotes pro-apoptotic Bax translocation to the mitochondria in neuronal apoptosis [147]. Others have found that Bcl-2 multi-site phosphorylation frees Beclin-1 to promote autophagy [148]. Additional work using phospho-mimetics and phospho-null mutations have produced conflicting results in different contexts (reviewed in [144]).

Many early studies on Bcl-2 family phosphorylation were performed in the context of microtubule-targeting agent (MTA) treatment, which induces multi-site phosphorylation of Bcl-2, Bcl-xL and Mcl-1 [149-153]. For Mcl-1, this leads to degradation. For Bcl-2 and Bcl$\mathrm{xL}$, this (poly)-phosphorylation seems to reduce their ability to sequester pro-apoptotic BH3-only proteins, though to what extent remains under debate [154]. Interestingly, Bcl-2 and $\mathrm{Bcl}-\mathrm{xL}$ are also normally phosphorylated during mitosis, the exact function of which remains to be clarified [155]. There is also some ambiguity in the literature, as not all phosphorylation sites were interrogated in the different studies. In contrast, biophysical characterization shows that Bcl-2 Ser70 mono-phosphorylation increases binding affinity for Bak and Bim, thereby making it a more potent inhibitor of apoptosis [156]. To complicate matters, this study also found that both Glu and Ala mutations at all known Bcl-2 phosphorylation sites showed increased affinity for Bak. The Ser70 mutants also showed increased accessibility to proteolysis. It was hypothesized that these phosphorylation events may expose the flexible loop of Bcl-2. It has not been tested whether Bcl-xL may undergo a similar conformational change upon phosphorylation. If so, the conclusions generated by "phospho-null" Ala mutations may need to be revisited [157-159,151]. Some work has suggested that Ser62-phosphorylated Bcl-xL does have reduced ability to sequester Bax 
[151]. Clearly, there is further work to be done to clarify the effects of these several phosphorylation events on Bcl-2/Bcl-xL. For many years, PP2A was the only phosphatase known to dephosphorylate these Bcl-2 family members, with both PP2A-B56a and -B56 being implicated in Bcl-2 dephosphorylation [145,146,158,160]. A related PSP, PP6, was recently shown to act as a Bcl-xL phosphatase in a murine $\mathrm{B}$ cell line to prevent its proteasomal degradation [161]. Moreover, both Bcl-xL and Bcl-w interact with PP1a but it is unclear whether or not these two anti-apoptotic proteins are PP1 substrates [162].

In addition to its activity towards anti-apoptotic Bcl-2 family members, PP2A has been implicated in dephosphorylating pro-apoptotic proteins Bad (as previously mentioned) and Bax to promote apoptosis $[139,163]$. Furthermore, PP2A can dephosphorylate Bim in a manner that prevents its proteasomal degradation [164]. The indirect PP2A activator FTY720 was also shown to increase Bim as well as truncated Bid (t-Bid) levels in CML cells [165]. Ceramide, another indirect PP2A activator, was also shown to increase t-Bid levels [166]. However, the exact relationship between PP2A and the regulation of Bid remains unclear. Conversely, PP2A has also been implicated in dephosphorylation of Bcl-xL at Ser62, which was shown to enhance its anti-apoptotic function [158]. In most of these cases, the specific B subunit that coordinates target specificity has not been identified. As PP2A has emerged as a promising therapeutic target, the potential for synergistic or inhibitory effects of combinatorial strategies employing PP2A-modulating agents with MTAs and other chemotherapies must be carefully considered.

Anti-apoptotic Mcl-1 is somewhat unique among Bcl-2 family members in its larger size and presence of additional regulatory motifs. A number of kinases, including GSK-3 $\beta$ and ERK, CDK-1, can phosphorylate Mcl-1 (Reviewed in [167]). Mcl-1 phosphorylation at Ser64 enhances its anti-apoptotic activity [168], whereas Ser159 phosphorylation by GSK-3 promotes its proteasomal degradation $[169,170]$. These examples highlight the possible proand anti-apoptotic effect of phosphorylation on Mcl-1. There are additional phosphorylation sites on Mcl-1 to which varied functions are attributed (reviewed in [167,171]). As for the role of phosphatases in Mcl-1 regulation, two indirectly-acting PP2A activating drugs, OP449 and FTY720, were shown to decrease Mcl-1 levels in CLL cells [172,173]. In lung cancer cells, PP2A knockdown or OA treatment increased Mcl-1 levels in multiple contexts $[174,115]$. These pharmacologic data suggest that PP2A may promote Mcl-1 degradation. This possible mechanism has yet to be definitively addressed. However, the Ruvolo lab demonstrated that C6-ceramide, whose effects include PP2A activation, led to JNKdependent increase in Mcl-1 phosphorylation at an undetermined site [175]. Thus, the effect of PP2A on Mcl-1 phosphorylation may be indirect. As Bcl-xL phosphorylation was also increased in these experiments, it may be that ceramide produces a mitotic arrest that leads to subsequent Bcl-2 family member PTMs [176]. However, a different study showed that both pharmacologic and genetic PP2A inhibition led to increased Mcl-1 phosphorylation and subsequent decrease in Mcl-1 protein levels in a Burkitt lymphoma cell line [160]. It will be essential to further understand the role of PP2A and other phosphatases in the control of Mcl-1, as it is an important mediator of cancer cell survival and chemoresistance. 


\section{Regulation of the Extrinsic Apoptotic Pathway by Phosphatase Signaling}

Phosphorylation of Bid on several Ser/Thr residues reduces its cleavage by caspase-8 downstream of Fas activation [177]. This phosphorylation appears to uncouple or at least delay death receptor activation from commitment to apoptosis [178]. However, we are unaware of any data implicating a specific phosphatase to counter this phosphorylation event, though it was speculated that PP2A may be involved [177]. It has been shown that reexpression of PTEN sensitizes LnCap cells to the extrinsic pathway and increases Bid cleavage but this sensitization occurs at the level of increased caspase- 8 cleavage [179]. This PTP more likely enhances apoptosis through its effects on the PI3K/AKT pathway.

Among PTPs, recent work found that SHP-1 dephosphorylates Tyr238 and Tyr291 on Fas to promote apoptosis [180]. In addition, SHP-1 dephosphorylates caspase-8, again with a proapoptotic effect [181]. However, there is competing data on whether SHP-1 promotes or inhibits extrinsic apoptosis (Reviewed in [182]). Its effects on cell death may be context or cell type dependent. Fas-associated phosphatase-1 (FAP-1, encoded by the PTPN13 gene), another PTP, inhibits Fas-activation of the extrinsic apoptotic pathway, potentially by dephosphorylation of Fas (as demonstrated in vitro [183]) or by preventing surface expression of Fas [184]. However, among other reported functions (dephosphorylation of IRS-1, HER-2, STAT4, etc.) this non-receptor PTP also dephosphorylates I $\mathrm{Ba}$, which serves to attenuate NF- $\kappa B$ activation (reviewed in [185]). Interestingly, FAP-1 is a transcriptional target of NF- $\kappa \mathrm{B}$, meaning that FAP-1 may serve to block Fas-mediated apoptosis in cancers with constitutive NF- $\kappa$ B activity [186,187]. Thus, FAP-1 exhibits characteristics of both an oncogene and a tumor suppressor but its phosphatase activity appears to function as the latter. Finally, the DUSP MKP-1 is overexpressed in prostate cancer where it inhibits Fas ligand (FasL)-induced apoptosis [188]. This phosphatase preferentially targets $\mathrm{p} 38$ and JNK. These examples show that PTPs exert both inhibitory and activating effects on extrinsic apoptosis.

Yet, not only PTPs contribute to the regulation of extrinsic apoptosis. In fact, pharmacologic or genetic inhibition of PP2A reduced Fas-induced apoptosis [189]. Furthermore, FasLinduced apoptosis of neutrophils correlates with a rapid induction of PP2A activity and PP2A can dephosphorylate caspase-3 in vitro, a pro-apoptotic event [190]. In this way and with its effects on Bcl-2 family members, PP2A may serve to cross-activate the intrinsic pathway to help amplify extrinsic death signals. However, some inhibitor experiments suggest that PP1 plays a more important role than PP2A in controlling the extrinsic pathway [191].

In summary, two general patterns emerge from existing data on phosphatase signaling in the control of apoptosis. First, dephosphorylation more commonly exerts a pro-apoptotic function, which is not surprising. Second, current data suggests that PTPs have a greater role in regulating the extrinsic apoptosis pathway, whereas PSPs exert more regulatory control over Bcl-2 family members. As with any biological system these rules have exceptions, some of which are highlighted above. 


\section{Targeting Phosphatases in Cancer}

Given the contribution of aberrant phosphatase signaling to oncogenic pathways, including those examples detailed herein, there exists strong rationale to seek therapeutic benefit via judicious targeting of these enzymes in appropriate contexts, especially as part of combination therapies. For tumor suppressive phosphatases that are lost in cancer, direct targeting is not an option. However, such aberrations may engender sensitivity to other targeted agents. For example, PTEN deficiency may determine susceptibility to certain therapeutics (reviewed in [192]). In addition, some phosphatases are inhibited by nondeletional mechanisms. In this context, as with PP2A, activating the phosphatase activity has been demonstrated to be a promising therapeutic approach [193-195]. In other circumstances innovative approaches to restoring phosphatase activity may be required.

Targeting oncogenic phosphatases may be a more straight-forward endeavor. Several inhibitors of oncogenic PTPs are in various stages of development, as outlined in several recent reviews $[8,196,185]$. For PP2A, in addition to activation strategies researchers are investigating its inhibition for treatment of various cancers [197]. These opposing approaches each have merit in that different PP2A holoenzymes possess either tumor suppressive or oncogenic functions. Time will tell whether one or both of these approaches to targeting PP2A will provide clinical benefit. Moreover, selectively targeting individual PP2A holoenzymes may be necessary to maximize the potential of this therapeutic strategy. There are a number of recent reviews that discuss the therapeutic targeting of PP2A and other PSPs in cancer [9,198,15,199-201,197,202].

One theme that recurs throughout this review is the potential context-dependence and/or holoenzyme specificity to the tumorigenic or tumor suppressive roles of various phosphatases. This complexity and the apparently contradictory roles of some phosphatases render their eventual therapeutic targeting even more challenging. As such, many levels of scientific inquiry are still needed to determine the best applications of phosphatase-targeting agents in cancer [203]. Such efforts represent the next step toward the ultimate goal of turning knowledge of phosphatase functions in cancer into cures and prolonged life for cancer patients.

\section{Conclusions and Future Perspectives}

In this review, we have illustrated multi-faceted control over several key oncogenic growth and survival pathways by phosphatases. Additionally, we have outlined examples where deregulation of phosphatase signaling contributes to cancer development and where it appears to cooperate with additional oncogenic aberrations to promote tumorigenesis. Moreover, some phosphatases exert both oncogenic and tumor suppressive functions, likely depending on cellular context. While the majority of data agrees with the long-standing concept that phosphatases act as an "off" switch for kinase-activated oncogenic activity, important examples are given wherein phosphatase activity drives proliferation and/or survival. With the wealth of information that has emerged about phosphatase-mediated control of oncogenic processes, we are approaching a point where these gains will soon translate to novel therapies for cancer and other diseases. Yet, our expanded knowledge has 
also unveiled potential complications in targeting phosphatases in cancer. For one, are enzymes with both oncogenic and tumor suppressive functions off limits as drug targets? For multimeric phosphatases, can we target individual holoenzymes to attain specificity for desired substrates? Does loss or mutation of specific subunits alter sensitivity to phosphatase-targeted or other therapies? What therapeutic strategies will show combinatorial effects with phosphatase inhibitors/activators and which ones may be antagonistic? As the field progresses, we will continue to address these questions. In doing so the potential to derive therapeutic gain from targeting phosphatases will likely come to fruition.

\section{References}

1. Lemmon MA, Freed DM, Schlessinger J, Kiyatkin A. The Dark Side of Cell Signaling: Positive Roles for Negative Regulators. Cell. 2016; 164(6):1172-1184. DOI: 10.1016/j.cell.2016.02.047 [PubMed: 26967284]

2. Gross S, Rahal R, Stransky N, Lengauer C, Hoeflich KP. Targeting cancer with kinase inhibitors. J Clin Invest. 2015; 125(5):1780-1789. DOI: 10.1172/JCI76094 [PubMed: 25932675]

3. Stebbing J, Lit LC, Zhang H, Darrington RS, Melaiu O, Rudraraju B, Giamas G. The regulatory roles of phosphatases in cancer. Oncogene. 2014; 33(8):939-953. DOI: 10.1038/onc.2013.80 [PubMed: 23503460]

4. Li J, Yen C, Liaw D, Podsypanina K, Bose S, Wang SI, Puc J, Miliaresis C, Rodgers L, McCombie R, Bigner SH, Giovanella BC, Ittmann M, Tycko B, Hibshoosh H, Wigler MH, Parsons R. PTEN, a putative protein tyrosine phosphatase gene mutated in human brain, breast, and prostate cancer. Science. 1997; 275(5308):1943-1947. [PubMed: 9072974]

5. Steck PA, Pershouse MA, Jasser SA, Yung WK, Lin H, Ligon AH, Langford LA, Baumgard ML, Hattier T, Davis T, Frye C, Hu R, Swedlund B, Teng DH, Tavtigian SV. Identification of a candidate tumour suppressor gene, MMAC1, at chromosome 10q23.3 that is mutated in multiple advanced cancers. Nat Genet. 1997; 15(4):356-362. DOI: 10.1038/ng0497-356 [PubMed: 9090379]

6. Stanford SM, Bottini N. Targeting Tyrosine Phosphatases: Time to End the Stigma. Trends Pharmacol Sci. 2017; 38(6):524-540. DOI: 10.1016/j.tips.2017.03.004 [PubMed: 28412041]

7. Olsen JV, Blagoev B, Gnad F, Macek B, Kumar C, Mortensen P, Mann M. Global, in vivo, and sitespecific phosphorylation dynamics in signaling networks. Cell. 2006; 127(3):635-648. DOI: 10.1016/j.cell.2006.09.026 [PubMed: 17081983]

8. Frankson R, Yu ZH, Bai Y, Li Q, Zhang RY, Zhang ZY. Therapeutic Targeting of Oncogenic Tyrosine Phosphatases. Cancer Res. 2017; 77(21):5701-5705. DOI: 10.1158/0008-5472.CAN-17-1510 [PubMed: 28855209]

9. Zhang M, Yogesha SD, Mayfield JE, Gill GN, Zhang Y. Viewing serine/threonine protein phosphatases through the eyes of drug designers. FEBS J. 2013; 280(19):4739-4760. DOI: 10.1111/ febs.12481 [PubMed: 23937612]

10. Tonks NK. Protein tyrosine phosphatases-from housekeeping enzymes to master regulators of signal transduction. FEBS J. 2013; 280(2):346-378. DOI: 10.1111/febs.12077 [PubMed: 23176256]

11. Alonso A, Sasin J, Bottini N, Friedberg I, Friedberg I, Osterman A, Godzik A, Hunter T, Dixon J, Mustelin T. Protein tyrosine phosphatases in the human genome. Cell. 2004; 117(6):699-711. DOI: 10.1016/j.cell.2004.05.018 [PubMed: 15186772]

12. Alonso A, Pulido R. The extended human PTPome: a growing tyrosine phosphatase family. FEBS J. 2016; 283(8):1404-1429. DOI: 10.1111/febs.13600 [PubMed: 26573778]

13. Elson A. Stepping out of the shadows: Oncogenic and tumor-promoting protein tyrosine phosphatases. Int J Biochem Cell Biol. 2017; doi: 10.1016/j.biocel.2017.09.013

14. Meeusen B, Janssens V. Tumor suppressive protein phosphatases in human cancer: emerging targets for therapeutic intervention and tumor stratification. Int J Biochem Cell Biol. 2017; doi: 10.1016/j.biocel.2017.10.002 
15. Sangodkar J, Farrington CC, McClinch K, Galsky MD, Kastrinsky DB, Narla G. All roads lead to PP2A: exploiting the therapeutic potential of this phosphatase. FEBS J. 2016; 283(6):1004-1024. DOI: 10.1111/febs.13573 [PubMed: 26507691]

16. Ruvolo PP. The broken "Off" switch in cancer signaling: PP2A as a regulator of tumorigenesis, drug resistance, and immune surveillance. BBA Clin. 2016; 6:87-99. DOI: 10.1016/j.bbacli. 2016.08.002 [PubMed: 27556014]

17. Hanahan D, Weinberg RA. The hallmarks of cancer. Cell. 2000; 100(1):57-70. [PubMed: 10647931]

18. Hanahan D, Weinberg RA. Hallmarks of cancer: the next generation. Cell. 2011; 144(5):646-674. DOI: 10.1016/j.cell.2011.02.013 [PubMed: 21376230]

19. Hollander MC, Blumenthal GM, Dennis PA. PTEN loss in the continuum of common cancers, rare syndromes and mouse models. Nat Rev Cancer. 2011; 11(4):289-301. DOI: 10.1038/nrc3037 [PubMed: 21430697]

20. Bentires-Alj M, Paez JG, David FS, Keilhack H, Halmos B, Naoki K, Maris JM, Richardson A, Bardelli A, Sugarbaker DJ, Richards WG, Du J, Girard L, Minna JD, Loh ML, Fisher DE, Velculescu VE, Vogelstein B, Meyerson M, Sellers WR, Neel BG. Activating mutations of the noonan syndrome-associated SHP2/PTPN11 gene in human solid tumors and adult acute myelogenous leukemia. Cancer Res. 2004; 64(24):8816-8820. DOI: 10.1158/0008-5472.CAN-04-1923 [PubMed: 15604238]

21. Tartaglia M, Niemeyer CM, Fragale A, Song X, Buechner J, Jung A, Hahlen K, Hasle H, Licht JD, Gelb BD. Somatic mutations in PTPN11 in juvenile myelomonocytic leukemia, myelodysplastic syndromes and acute myeloid leukemia. Nat Genet. 2003; 34(2):148-150. DOI: 10.1038/ng1156 [PubMed: 12717436]

22. Engelman JA, Luo J, Cantley LC. The evolution of phosphatidylinositol 3-kinases as regulators of growth and metabolism. Nat Rev Genet. 2006; 7(8):606-619. DOI: 10.1038/nrg1879 [PubMed: 16847462]

23. Vanhaesebroeck B, Guillermet-Guibert J, Graupera M, Bilanges B. The emerging mechanisms of isoform-specific PI3K signalling. Nat Rev Mol Cell Biol. 2010; 11(5):329-341. DOI: 10.1038/ nrm2882 [PubMed: 20379207]

24. Luo J, Manning BD, Cantley LC. Targeting the PI3K-Akt pathway in human cancer: rationale and promise. Cancer Cell. 2003; 4(4):257-262. [PubMed: 14585353]

25. Engelman JA. Targeting PI3K signalling in cancer: opportunities, challenges and limitations. Nat Rev Cancer. 2009; 9(8):550-562. DOI: 10.1038/nrc2664 [PubMed: 19629070]

26. Robbins HL, Hague A. The PI3K/Akt Pathway in Tumors of Endocrine Tissues. Front Endocrinol (Lausanne). 2015; 6:188.doi: 10.3389/fendo.2015.00188 [PubMed: 26793165]

27. Fruman DA, Chiu H, Hopkins BD, Bagrodia S, Cantley LC, Abraham RT. The PI3K Pathway in Human Disease. Cell. 2017; 170(4):605-635. DOI: 10.1016/j.cell.2017.07.029 [PubMed: 28802037]

28. Zehir A, Benayed R, Shah RH, Syed A, Middha S, Kim HR, Srinivasan P, Gao J, Chakravarty D, Devlin SM, Hellmann MD, Barron DA, Schram AM, Hameed M, Dogan S, Ross DS, Hechtman JF, DeLair DF, Yao J, Mandelker DL, Cheng DT, Chandramohan R, Mohanty AS, Ptashkin RN, Jayakumaran G, Prasad M, Syed MH, Rema AB, Liu ZY, Nafa K, Borsu L, Sadowska J, Casanova J, Bacares R, Kiecka IJ, Razumova A, Son JB, Stewart L, Baldi T, Mullaney KA, Al-Ahmadie H, Vakiani E, Abeshouse AA, Penson AV, Jonsson P, Camacho N, Chang MT, Won HH, Gross BE, Kundra R, Heins ZJ, Chen HW, Phillips S, Zhang H, Wang J, Ochoa A, Wills J, Eubank M, Thomas SB, Gardos SM, Reales DN, Galle J, Durany R, Cambria R, Abida W, Cercek A, Feldman DR, Gounder MM, Hakimi AA, Harding JJ, Iyer G, Janjigian YY, Jordan EJ, Kelly CM, Lowery MA, Morris LGT, Omuro AM, Raj N, Razavi P, Shoushtari AN, Shukla N, Soumerai TE, Varghese AM, Yaeger R, Coleman J, Bochner B, Riely GJ, Saltz LB, Scher HI, Sabbatini PJ, Robson ME, Klimstra DS, Taylor BS, Baselga J, Schultz N, Hyman DM, Arcila ME, Solit DB, Ladanyi M, Berger MF. Mutational landscape of metastatic cancer revealed from prospective clinical sequencing of 10,000 patients. Nat Med. 2017; 23(6):703-713. DOI: 10.1038/nm.4333 [PubMed: 28481359] 
29. Maehama T, Dixon JE. The tumor suppressor, PTEN/MMAC1, dephosphorylates the lipid second messenger, phosphatidylinositol 3,4,5-trisphosphate. J Biol Chem. 1998; 273(22):13375-13378. [PubMed: 9593664]

30. Bigner SH, Mark J, Mahaley MS, Bigner DD. Patterns of the early, gross chromosomal changes in malignant human gliomas. Hereditas. 1984; 101(1):103-113. [PubMed: 6490389]

31. Liaw D, Marsh DJ, Li J, Dahia PL, Wang SI, Zheng Z, Bose S, Call KM, Tsou HC, Peacocke M, Eng C, Parsons R. Germline mutations of the PTEN gene in Cowden disease, an inherited breast and thyroid cancer syndrome. Nat Genet. 1997; 16(1):64-67. DOI: 10.1038/ng0597-64 [PubMed: 9140396]

32. Shojaee S, Chan LN, Buchner M, Cazzaniga V, Cosgun KN, Geng H, Qiu YH, von Minden MD, Ernst T, Hochhaus A, Cazzaniga G, Melnick A, Kornblau SM, Graeber TG, Wu H, Jumaa H, Muschen M. PTEN opposes negative selection and enables oncogenic transformation of pre-B cells. Nat Med. 2016; 22(4):379-387. DOI: 10.1038/nm.4062 [PubMed: 26974310]

33. Grzechnik AT, Newton AC. PHLPPing through history: a decade in the life of PHLPP phosphatases. Biochem Soc Trans. 2016; 44(6):1675-1682. DOI: 10.1042/BST20160170 [PubMed: 27913677]

34. Gao T, Furnari F, Newton AC. PHLPP: a phosphatase that directly dephosphorylates Akt, promotes apoptosis, and suppresses tumor growth. Mol Cell. 2005; 18(1):13-24. DOI: 10.1016/j.molcel. 2005.03.008 [PubMed: 15808505]

35. Brognard J, Sierecki E, Gao T, Newton AC. PHLPP and a second isoform, PHLPP2, differentially attenuate the amplitude of Akt signaling by regulating distinct Akt isoforms. Mol Cell. 2007; 25(6):917-931. DOI: 10.1016/j.molcel.2007.02.017 [PubMed: 17386267]

36. Gao T, Brognard J, Newton AC. The phosphatase PHLPP controls the cellular levels of protein kinase C. J Biol Chem. 2008; 283(10):6300-6311. DOI: 10.1074/jbc.M707319200 [PubMed: 18162466]

37. Liu J, Stevens PD, Li X, Schmidt MD, Gao T. PHLPP-mediated dephosphorylation of S6K1 inhibits protein translation and cell growth. Mol Cell Biol. 2011; 31(24):4917-4927. DOI: 10.1128/MCB.05799-11 [PubMed: 21986499]

38. Chen H, Zhang K, Wu G, Song D, Chen K, Yang H. Low expression of PHLPP1 in sacral chordoma and its association with poor prognosis. Int J Clin Exp Pathol. 2015; 8(11):1474114748. [PubMed: 26823799]

39. Goel A, Arnold CN, Niedzwiecki D, Chang DK, Ricciardiello L, Carethers JM, Dowell JM, Wasserman L, Compton C, Mayer RJ, Bertagnolli MM, Boland CR. Characterization of sporadic colon cancer by patterns of genomic instability. Cancer Res. 2003; 63(7):1608-1614. [PubMed: 12670912]

40. Johnson-Pais TL, Nellissery MJ, Ammerman DG, Pathmanathan D, Bhatia P, Buller CL, Leach RJ, Hansen MF. Determination of a minimal region of loss of heterozygosity on chromosome 18q21.33 in osteosarcoma. Int J Cancer. 2003; 105(2):285-288. DOI: 10.1002/ijc.11070 [PubMed: 12673693]

41. Nitsche C, Edderkaoui M, Moore RM, Eibl G, Kasahara N, Treger J, Grippo PJ, Mayerle J, Lerch MM, Gukovskaya AS. The phosphatase PHLPP1 regulates Akt2, promotes pancreatic cancer cell death, and inhibits tumor formation. Gastroenterology. 2012; 142(2):377-387. e371-375. DOI: 10.1053/j.gastro.2011.10.026 [PubMed: 22044669]

42. Rakha EA, Green AR, Powe DG, Roylance R, Ellis IO. Chromosome 16 tumor-suppressor genes in breast cancer. Genes Chromosomes Cancer. 2006; 45(6):527-535. DOI: 10.1002/gcc.20318 [PubMed: 16518845]

43. Teng DC, Sun J, An YQ, Hu ZH, Liu P, Ma YC, Han B, Shi Y. Role of PHLPP1 in inflammation response: Its loss contributes to gliomas development and progression. Int Immunopharmacol. 2016; 34:229-234. DOI: 10.1016/j.intimp.2016.02.034 [PubMed: 26971226]

44. Andjelkovic M, Jakubowicz T, Cron P, Ming XF, Han JW, Hemmings BA. Activation and phosphorylation of a pleckstrin homology domain containing protein kinase (RAC-PK/PKB) promoted by serum and protein phosphatase inhibitors. Proc Natl Acad Sci U S A. 1996; 93(12): 5699-5704. [PubMed: 8650155] 
45. Chen D, Fucini RV, Olson AL, Hemmings BA, Pessin JE. Osmotic shock inhibits insulin signaling by maintaining Akt/protein kinase B in an inactive dephosphorylated state. Mol Cell Biol. 1999; 19(7):4684-4694. [PubMed: 10373517]

46. Ivaska J, Nissinen L, Immonen N, Eriksson JE, Kahari VM, Heino J. Integrin alpha 2 beta 1 promotes activation of protein phosphatase $2 \mathrm{~A}$ and dephosphorylation of Akt and glycogen synthase kinase 3 beta. Mol Cell Biol. 2002; 22(5):1352-1359. [PubMed: 11839802]

47. Meier R, Thelen M, Hemmings BA. Inactivation and dephosphorylation of protein kinase Balpha (PKBalpha) promoted by hyperosmotic stress. EMBO J. 1998; 17(24):7294-7303. DOI: 10.1093/ emboj/17.24.7294 [PubMed: 9857186]

48. Resjo S, Goransson O, Harndahl L, Zolnierowicz S, Manganiello V, Degerman E. Protein phosphatase $2 \mathrm{~A}$ is the main phosphatase involved in the regulation of protein kinase $\mathrm{B}$ in rat adipocytes. Cell Signal. 2002; 14(3):231-238. [PubMed: 11812651]

49. Kuo YC, Huang KY, Yang CH, Yang YS, Lee WY, Chiang CW. Regulation of phosphorylation of Thr-308 of Akt, cell proliferation, and survival by the B55alpha regulatory subunit targeting of the protein phosphatase 2A holoenzyme to Akt. J Biol Chem. 2008; 283(4):1882-1892. DOI: 10.1074/ jbc.M709585200 [PubMed: 18042541]

50. Padmanabhan S, Mukhopadhyay A, Narasimhan SD, Tesz G, Czech MP, Tissenbaum HA. A PP2A regulatory subunit regulates $\mathrm{C}$. elegans insulin/IGF-1 signaling by modulating AKT-1 phosphorylation. Cell. 2009; 136(5):939-951. DOI: 10.1016/j.cell.2009.01.025 [PubMed: 19249087]

51. Chen W, Possemato R, Campbell KT, Plattner CA, Pallas DC, Hahn WC. Identification of specific PP2A complexes involved in human cell transformation. Cancer Cell. 2004; 5(2):127-136. [PubMed: 14998489]

52. Ruvolo PP, Ruvolo VR, Jacamo R, Burks JK, Zeng Z, Duvvuri SR, Zhou L, Qiu Y, Coombes KR, Zhang N, Yoo SY, Pan R, Hail N Jr, Konopleva M, Calin G, Kornblau SM, Andreeff M. The protein phosphatase $2 \mathrm{~A}$ regulatory subunit B55alpha is a modulator of signaling and microRNA expression in acute myeloid leukemia cells. Biochim Biophys Acta. 2014; 1843(9):1969-1977. DOI: 10.1016/j.bbamcr.2014.05.006 [PubMed: 24858343]

53. Shouse G, de Necochea-Campion R, Mirshahidi S, Liu X, Chen CS. Novel B55alpha-PP2A mutations in AML promote AKT T308 phosphorylation and sensitivity to AKT inhibitor-induced growth arrest. Oncotarget. 2016; 7(38):61081-61092. DOI: 10.18632/oncotarget.11209 [PubMed: 27531894]

54. Curtis C, Shah SP, Chin SF, Turashvili G, Rueda OM, Dunning MJ, Speed D, Lynch AG, Samarajiwa S, Yuan Y, Graf S, Ha G, Haffari G, Bashashati A, Russell R, McKinney S, Group M. Langerod A, Green A, Provenzano E, Wishart G, Pinder S, Watson P, Markowetz F, Murphy L, Ellis I, Purushotham A, Borresen-Dale AL, Brenton JD, Tavare S, Caldas C, Aparicio S. The genomic and transcriptomic architecture of 2,000 breast tumours reveals novel subgroups. Nature. 2012; 486(7403):346-352. DOI: 10.1038/nature10983 [PubMed: 22522925]

55. Liu W, Xie CC, Zhu Y, Li T, Sun J, Cheng Y, Ewing CM, Dalrymple S, Turner AR, Sun J, Isaacs JT, Chang BL, Zheng SL, Isaacs WB, Xu J. Homozygous deletions and recurrent amplifications implicate new genes involved in prostate cancer. Neoplasia. 2008; 10(8):897-907. [PubMed: 18670647]

56. Mosca L, Musto P, Todoerti K, Barbieri M, Agnelli L, Fabris S, Tuana G, Lionetti M, Bonaparte E, Sirchia SM, Grieco V, Bianchino G, D’Auria F, Statuto T, Mazzoccoli C, De Luca L, Petrucci MT, Morabito F, Offidani M, Di Raimondo F, Falcone A, Caravita T, Omede P, Boccadoro M, Palumbo A, Neri A. Genome-wide analysis of primary plasma cell leukemia identifies recurrent imbalances associated with changes in transcriptional profiles. Am J Hematol. 2013; 88(1):16-23. DOI: 10.1002/ajh.23339 [PubMed: 23044976]

57. Downward J. Targeting RAS signalling pathways in cancer therapy. Nat Rev Cancer. 2003; 3(1): 11-22. DOI: 10.1038/nrc969 [PubMed: 12509763]

58. Herrero A, Matallanas D, Kolch W. The spatiotemporal regulation of RAS signalling. Biochem Soc Trans. 2016; 44(5):1517-1522. DOI: 10.1042/BST20160127 [PubMed: 27911734]

59. Li X, Stevens PD, Liu J, Yang H, Wang W, Wang C, Zeng Z, Schmidt MD, Yang M, Lee EY, Gao T. PHLPP is a negative regulator of RAF1, which reduces colorectal cancer cell motility and 
prevents tumor progression in mice. Gastroenterology. 2014; 146(5):1301-1312. e1301-1310. DOI: 10.1053/j.gastro.2014.02.003 [PubMed: 24530606]

60. Gagne-Sansfacon J, Coulombe G, Langlois MJ, Langlois A, Paquet M, Carrier J, Feng GS, Qu CK, Rivard N. SHP-2 phosphatase contributes to KRAS-driven intestinal oncogenesis but prevents colitis-associated cancer development. Oncotarget. 2016; 7(40):65676-65695. DOI: 10.18632/ oncotarget.11601 [PubMed: 27582544]

61. Adams DG, Coffee RL Jr, Zhang H, Pelech S, Strack S, Wadzinski BE. Positive regulation of Raf1-MEK1/2-ERK1/2 signaling by protein serine/threonine phosphatase 2A holoenzymes. J Biol Chem. 2005; 280(52):42644-42654. DOI: 10.1074/jbc.M502464200 [PubMed: 16239230]

62. Ory S, Zhou M, Conrads TP, Veenstra TD, Morrison DK. Protein phosphatase 2A positively regulates Ras signaling by dephosphorylating KSR1 and Raf-1 on critical 14-3-3 binding sites. Curr Biol. 2003; 13(16):1356-1364. [PubMed: 12932319]

63. Hein AL, Seshacharyulu P, Rachagani S, Sheinin YM, Ouellette MM, Ponnusamy MP, Mumby MC, Batra SK, Yan Y. PR55alpha Subunit of Protein Phosphatase 2A Supports the Tumorigenic and Metastatic Potential of Pancreatic Cancer Cells by Sustaining Hyperactive Oncogenic Signaling. Cancer Res. 2016; 76(8):2243-2253. DOI: 10.1158/0008-5472.CAN-15-2119 [PubMed: 26893480]

64. Shen S, Yue H, Li Y, Qin J, Li K, Liu Y, Wang J. Upregulation of miR-136 in human non-small cell lung cancer cells promotes Erk1/2 activation by targeting PPP2R2A. Tumour Biol. 2014; 35(1):631-640. DOI: 10.1007/s13277-013-1087-2 [PubMed: 23959478]

65. Haagenson KK, Wu GS. Mitogen activated protein kinase phosphatases and cancer. Cancer Biol Ther. 2010; 9(5):337-340. [PubMed: 20139719]

66. Nunes-Xavier C, Roma-Mateo C, Rios P, Tarrega C, Cejudo-Marin R, Tabernero L, Pulido R. Dual-specificity MAP kinase phosphatases as targets of cancer treatment. Anticancer Agents Med Chem. 2011; 11(1):109-132. [PubMed: 21288197]

67. Calvisi DF, Pinna F, Meloni F, Ladu S, Pellegrino R, Sini M, Daino L, Simile MM, De Miglio MR, Virdis P, Frau M, Tomasi ML, Seddaiu MA, Muroni MR, Feo F, Pascale RM. Dual-specificity phosphatase 1 ubiquitination in extracellular signal-regulated kinase-mediated control of growth in human hepatocellular carcinoma. Cancer Res. 2008; 68(11):4192-4200. DOI: 10.1158/0008-5472.CAN-07-6157 [PubMed: 18519678]

68. Denkert C, Schmitt WD, Berger S, Reles A, Pest S, Siegert A, Lichtenegger W, Dietel M, Hauptmann S. Expression of mitogen-activated protein kinase phosphatase-1 (MKP-1) in primary human ovarian carcinoma. Int J Cancer. 2002; 102(5):507-513. DOI: 10.1002/ijc.10746 [PubMed: 12432554]

69. Loda M, Capodieci P, Mishra R, Yao H, Corless C, Grigioni W, Wang Y, Magi-Galluzzi C, Stork PJ. Expression of mitogen-activated protein kinase phosphatase-1 in the early phases of human epithelial carcinogenesis. Am J Pathol. 1996; 149(5):1553-1564. [PubMed: 8909245]

70. Magi-Galluzzi C, Mishra R, Fiorentino M, Montironi R, Yao H, Capodieci P, Wishnow K, Kaplan I, Stork PJ, Loda M. Mitogen-activated protein kinase phosphatase 1 is overexpressed in prostate cancers and is inversely related to apoptosis. Lab Invest. 1997; 76(1):37-51. [PubMed: 9010448]

71. Manzano RG, Montuenga LM, Dayton M, Dent P, Kinoshita I, Vicent S, Gardner GJ, Nguyen P, Choi YH, Trepel J, Auersperg N, Birrer MJ. CL100 expression is down-regulated in advanced epithelial ovarian cancer and its re-expression decreases its malignant potential. Oncogene. 2002; 21(28):4435-4447. DOI: 10.1038/sj.onc.1205542 [PubMed: 12080474]

72. Rauhala HE, Porkka KP, Tolonen TT, Martikainen PM, Tammela TL, Visakorpi T. Dual-specificity phosphatase 1 and serum/glucocorticoid-regulated kinase are downregulated in prostate cancer. Int J Cancer. 2005; 117(5):738-745. DOI: 10.1002/ijc.21270 [PubMed: 15981206]

73. Shen J, Zhou S, Shi L, Liu X, Lin H, Yu H, Xiaoliang, Tang J, Yu T, Cai X. DUSP1 inhibits cell proliferation, metastasis and invasion and angiogenesis in gallbladder cancer. Oncotarget. 2017; 8(7):12133-12144. DOI: 10.18632/oncotarget.14815 [PubMed: 28129656]

74. Yokoyama A, Karasaki H, Urushibara N, Nomoto K, Imai Y, Nakamura K, Mizuno Y, Ogawa K, Kikuchi K. The characteristic gene expressions of MAPK phosphatases 1 and 2 in hepatocarcinogenesis, rat ascites hepatoma cells, and regenerating rat liver. Biochem Biophys Res Commun. 1997; 239(3):746-751. DOI: 10.1006/bbrc.1997.7547 [PubMed: 9367840] 
75. Boutros T, Chevet E, Metrakos P. Mitogen-activated protein (MAP) kinase/MAP kinase phosphatase regulation: roles in cell growth, death, and cancer. Pharmacol Rev. 2008; 60(3):261310. DOI: 10.1124/pr.107.00106 [PubMed: 18922965]

76. Wu GS. Role of mitogen-activated protein kinase phosphatases (MKPs) in cancer. Cancer Metastasis Rev. 2007; 26(3-4):579-585. DOI: 10.1007/s10555-007-9079-6 [PubMed: 17717636]

77. Britson JS, Barton F, Balko JM, Black EP. Deregulation of DUSP activity in EGFR-mutant lung cancer cell lines contributes to sustained ERK1/2 signaling. Biochem Biophys Res Commun. 2009; 390(3):849-854. DOI: 10.1016/j.bbrc.2009.10.061 [PubMed: 19836351]

78. Chitale D, Gong Y, Taylor BS, Broderick S, Brennan C, Somwar R, Golas B, Wang L, Motoi N, Szoke J, Reinersman JM, Major J, Sander C, Seshan VE, Zakowski MF, Rusch V, Pao W, Gerald W, Ladanyi M. An integrated genomic analysis of lung cancer reveals loss of DUSP4 in EGFRmutant tumors. Oncogene. 2009; 28(31):2773-2783. DOI: 10.1038/onc.2009.135 [PubMed: 19525976]

79. Mazumdar A, Poage GM, Shepherd J, Tsimelzon A, Hartman ZC, Den Hollander P, Hill J, Zhang Y, Chang J, Hilsenbeck SG, Fuqua S, Kent Osborne C, Mills GB, Brown PH. Analysis of phosphatases in ER-negative breast cancers identifies DUSP4 as a critical regulator of growth and invasion. Breast Cancer Res Treat. 2016; 158(3):441-454. DOI: 10.1007/s10549-016-3892-y [PubMed: 27393618]

80. Sieben NL, Oosting J, Flanagan AM, Prat J, Roemen GM, Kolkman-Uljee SM, van Eijk R, Cornelisse CJ, Fleuren GJ, van Engeland M. Differential gene expression in ovarian tumors reveals Dusp 4 and Serpina 5 as key regulators for benign behavior of serous borderline tumors. J Clin Oncol. 2005; 23(29):7257-7264. DOI: 10.1200/JCO.2005.02.2541 [PubMed: 16087957]

81. Lin SC, Chien CW, Lee JC, Yeh YC, Hsu KF, Lai YY, Lin SC, Tsai SJ. Suppression of dualspecificity phosphatase-2 by hypoxia increases chemoresistance and malignancy in human cancer cells. J Clin Invest. 2011; 121(5):1905-1916. DOI: 10.1172/JCI44362 [PubMed: 21490398]

82. Perander M, Al-Mahdi R, Jensen TC, Nunn JA, Kildalsen H, Johansen B, Gabrielsen M, Keyse SM, Seternes OM. Regulation of atypical MAP kinases ERK3 and ERK4 by the phosphatase DUSP2. Sci Rep. 2017; 7:43471.doi: 10.1038/srep43471 [PubMed: 28252035]

83. Yin Y, Liu YX, Jin YJ, Hall EJ, Barrett JC. PAC1 phosphatase is a transcription target of p53 in signalling apoptosis and growth suppression. Nature. 2003; 422(6931):527-531. DOI: 10.1038/ nature01519 [PubMed: 12673251]

84. Lammers T, Lavi S. Role of type $2 \mathrm{C}$ protein phosphatases in growth regulation and in cellular stress signaling. Crit Rev Biochem Mol Biol. 2007; 42(6):437-461. DOI: 10.1080/10409230701693342 [PubMed: 18066953]

85. Lu G, Wang Y. Functional diversity of mammalian type 2C protein phosphatase isoforms: new tales from an old family. Clin Exp Pharmacol Physiol. 2008; 35(2):107-112. DOI: 10.1111/j. 1440-1681.2007.04843.x [PubMed: 18197890]

86. Shi Y. Serine/threonine phosphatases: mechanism through structure. Cell. 2009; 139(3):468-484. DOI: 10.1016/j.cell.2009.10.006 [PubMed: 19879837]

87. Hanada M, Kobayashi T, Ohnishi M, Ikeda S, Wang H, Katsura K, Yanagawa Y, Hiraga A, Kanamaru R, Tamura S. Selective suppression of stress-activated protein kinase pathway by protein phosphatase 2C in mammalian cells. FEBS Lett. 1998; 437(3):172-176. [PubMed: 9824284]

88. Li R, Gong Z, Pan C, Xie DD, Tang JY, Cui M, Xu YF, Yao W, Pang Q, Xu ZG, Li MY, Yu X, Sun JP. Metal-dependent protein phosphatase 1A functions as an extracellular signal-regulated kinase phosphatase. FEBS J. 2013; 280(11):2700-2711. DOI: 10.1111/febs.12275 [PubMed: 23560844]

89. Lammers T, Peschke P, Ehemann V, Debus J, Slobodin B, Lavi S, Huber P. Role of PP2Calpha in cell growth, in radio- and chemosensitivity, and in tumorigenicity. Mol Cancer. 2007; 6:65.doi: 10.1186/1476-4598-6-65 [PubMed: 17941990]

90. Ofek P, Ben-Meir D, Kariv-Inbal Z, Oren M, Lavi S. Cell cycle regulation and p53 activation by protein phosphatase 2C alpha. J Biol Chem. 2003; 278(16):14299-14305. DOI: 10.1074/ jbc.M211699200 [PubMed: 12514180] 
91. Yang J, Yuan D, Li J, Zheng S, Wang B. miR-186 downregulates protein phosphatase PPM1B in bladder cancer and mediates G1-S phase transition. Tumour Biol. 2016; 37(4):4331-4341. DOI: 10.1007/s13277-015-4117-4 [PubMed: 26494000]

92. Zhou Y, Zhao Y, Gao Y, Hu W, Qu Y, Lou N, Zhu Y, Zhang X, Yang H. Hepatitis C virus NS3 protein enhances hepatocellular carcinoma cell invasion by promoting PPM1A ubiquitination and degradation. J Exp Clin Cancer Res. 2017; 36(1):42.doi: 10.1186/s13046-017-0510-8 [PubMed: 28283039]

93. Dang CV. MYC on the path to cancer. Cell. 2012; 149(1):22-35. DOI: 10.1016/j.cell.2012.03.003 [PubMed: 22464321]

94. Dani C, Blanchard JM, Piechaczyk M, El Sabouty S, Marty L, Jeanteur P. Extreme instability of myc mRNA in normal and transformed human cells. Proc Natl Acad Sci U S A. 1984; 81(22): 7046-7050. [PubMed: 6594679]

95. Hann SR, Eisenman RN. Proteins encoded by the human c-myc oncogene: differential expression in neoplastic cells. Mol Cell Biol. 1984; 4(11):2486-2497. [PubMed: 6513926]

96. Farrell AS, Sears RC. MYC degradation. Cold Spring Harb Perspect Med. 2014; 4(3)doi: 10.1101/ cshperspect.a014365

97. Farrell AS, Pelz C, Wang X, Daniel CJ, Wang Z, Su Y, Janghorban M, Zhang X, Morgan C, Impey $\mathrm{S}$, Sears RC. Pin1 regulates the dynamics of c-Myc DNA binding to facilitate target gene regulation and oncogenesis. Mol Cell Biol. 2013; 33(15):2930-2949. DOI: 10.1128/MCB. 01455-12 [PubMed: 23716601]

98. Sanchez-Arevalo Lobo VJ, Doni M, Verrecchia A, Sanulli S, Faga G, Piontini A, Bianchi M, Conacci-Sorrell M, Mazzarol G, Peg V, Losa JH, Ronchi P, Ponzoni M, Eisenman RN, Doglioni C, Amati B. Dual regulation of Myc by Abl. Oncogene. 2013; 32(45):5261-5271. DOI: 10.1038/onc. 2012.621 [PubMed: 23318434]

99. Arnold HK, Sears RC. Protein phosphatase 2A regulatory subunit B56alpha associates with c-myc and negatively regulates c-myc accumulation. Mol Cell Biol. 2006; 26(7):2832-2844. DOI: 10.1128/MCB.26.7.2832-2844.2006 [PubMed: 16537924]

100. Liu L, Eisenman RN. Regulation of c-Myc Protein Abundance by a Protein Phosphatase 2AGlycogen Synthase Kinase 3beta-Negative Feedback Pathway. Genes Cancer. 2012; 3(1):23-36. DOI: 10.1177/1947601912448067 [PubMed: 22893788]

101. Lambrecht C, Libbrecht L, Sagaert X, Pauwels P, Hoorne Y, Crowther J, Louis JV, Sents W, Sablina A, Janssens V. Loss of protein phosphatase 2A regulatory subunit B56delta promotes spontaneous tumorigenesis in vivo. Oncogene. 2017; doi: 10.1038/onc.2017.350

102. Xu J, Wong EY, Cheng C, Li J, Sharkar MT, Xu CY, Chen B, Sun J, Jing D, Xu PX. Eya1 interacts with Six2 and Myc to regulate expansion of the nephron progenitor pool during nephrogenesis. Dev Cell. 2014; 31(4):434-447. DOI: 10.1016/j.devcel.2014.10.015 [PubMed: 25458011]

103. Li J, Rodriguez Y, Cheng C, Zeng L, Wong EY, Xu CY, Zhou MM, Xu PX. EYA1's Conformation Specificity in Dephosphorylating Phosphothreonine in Myc and Its Activity on Myc Stabilization in Breast Cancer. Mol Cell Biol. 2017; 37(1)doi: 10.1128/MCB.00499-16

104. Yeh E, Cunningham M, Arnold H, Chasse D, Monteith T, Ivaldi G, Hahn WC, Stukenberg PT, Shenolikar S, Uchida T, Counter CM, Nevins JR, Means AR, Sears R. A signalling pathway controlling c-Myc degradation that impacts oncogenic transformation of human cells. Nat Cell Biol. 2004; 6(4):308-318. DOI: 10.1038/ncb1110 [PubMed: 15048125]

105. Zhou H, Zhang L, Vartuli RL, Ford HL, Zhao R. The Eya phosphatase: Its unique role in cancer. Int J Biochem Cell Biol. 2017; doi: 10.1016/j.biocel.2017.09.001

106. Tan J, Lee PL, Li Z, Jiang X, Lim YC, Hooi SC, Yu Q. B55beta-associated PP2A complex controls PDK1-directed myc signaling and modulates rapamycin sensitivity in colorectal cancer. Cancer Cell. 2010; 18(5):459-471. DOI: 10.1016/j.ccr.2010.10.021 [PubMed: 21075311]

107. Zhang X, Farrell AS, Daniel CJ, Arnold H, Scanlan C, Laraway BJ, Janghorban M, Lum L, Chen D, Troxell M, Sears R. Mechanistic insight into Myc stabilization in breast cancer involving aberrant Axin1 expression. Proc Natl Acad Sci U S A. 2012; 109(8):2790-2795. DOI: 10.1073/ pnas.1100764108 [PubMed: 21808024] 
108. Young RM, Polsky A, Refaeli Y. TC-PTP is required for the maintenance of MYC-driven B-cell lymphomas. Blood. 2009; 114(24):5016-5023. DOI: 10.1182/blood-2008-12-196709 [PubMed: 19755676]

109. Kleppe M, Lahortiga I, El Chaar T, De Keersmaecker K, Mentens N, Graux C, Van Roosbroeck K, Ferrando AA, Langerak AW, Meijerink JP, Sigaux F, Haferlach T, Wlodarska I, Vandenberghe P, Soulier J, Cools J. Deletion of the protein tyrosine phosphatase gene PTPN2 in T-cell acute lymphoblastic leukemia. Nat Genet. 2010; 42(6):530-535. DOI: 10.1038/ng.587 [PubMed: 20473312]

110. Kleppe M, Soulier J, Asnafi V, Mentens N, Hornakova T, Knoops L, Constantinescu S, Sigaux F, Meijerink JP, Vandenberghe P, Tartaglia M, Foa R, Macintyre E, Haferlach T, Cools J. PTPN2 negatively regulates oncogenic JAK1 in T-cell acute lymphoblastic leukemia. Blood. 2011; 117(26):7090-7098. DOI: 10.1182/blood-2010-10-314286 [PubMed: 21551237]

111. Kleppe M, Tousseyn T, Geissinger E, Kalender Atak Z, Aerts S, Rosenwald A, Wlodarska I, Cools J. Mutation analysis of the tyrosine phosphatase PTPN2 in Hodgkin's lymphoma and Tcell non-Hodgkin's lymphoma. Haematologica. 2011; 96(11):1723-1727. DOI: 10.3324/ haematol.2011.041921 [PubMed: 21791476]

112. Shields BJ, Wiede F, Gurzov EN, Wee K, Hauser C, Zhu HJ, Molloy TJ, O'Toole SA, Daly RJ, Sutherland RL, Mitchell CA, McLean CA, Tiganis T. TCPTP regulates SFK and STAT3 signaling and is lost in triple-negative breast cancers. Mol Cell Biol. 2013; 33(3):557-570. DOI: 10.1128/MCB.01016-12 [PubMed: 23166300]

113. Bowman T, Broome MA, Sinibaldi D, Wharton W, Pledger WJ, Sedivy JM, Irby R, Yeatman T, Courtneidge SA, Jove R. Stat3-mediated Myc expression is required for Src transformation and PDGF-induced mitogenesis. Proc Natl Acad Sci U S A. 2001; 98(13):7319-7324. DOI: 10.1073/ pnas.131568898 [PubMed: 11404481]

114. Bhat M, Robichaud N, Hulea L, Sonenberg N, Pelletier J, Topisirovic I. Targeting the translation machinery in cancer. Nat Rev Drug Discov. 2015; 14(4):261-278. DOI: 10.1038/nrd4505 [PubMed: 25743081]

115. Li Y, Yue P, Deng X, Ueda T, Fukunaga R, Khuri FR, Sun SY. Protein phosphatase 2A negatively regulates eukaryotic initiation factor 4E phosphorylation and eIF4F assembly through direct dephosphorylation of Mnk and eIF4E. Neoplasia. 2010; 12(10):848-855. [PubMed: 20927323]

116. Guan L, Song K, Pysz MA, Curry KJ, Hizli AA, Danielpour D, Black AR, Black JD. Protein kinase $\mathrm{C}$-mediated down-regulation of cyclin D1 involves activation of the translational repressor 4E-BP1 via a phosphoinositide 3-kinase/Akt-independent, protein phosphatase 2A-dependent mechanism in intestinal epithelial cells. J Biol Chem. 2007; 282(19):14213-14225. DOI: 10.1074/jbc.M610513200 [PubMed: 17360714]

117. Liu J, Stevens PD, Eshleman NE, Gao T. Protein phosphatase PPM1G regulates protein translation and cell growth by dephosphorylating 4E binding protein 1 (4E-BP1). J Biol Chem. 2013; 288(32):23225-23233. DOI: 10.1074/jbc.M113.492371 [PubMed: 23814053]

118. Khoronenkova SV, Dianova II, Ternette N, Kessler BM, Parsons JL, Dianov GL. ATM-dependent downregulation of USP7/HAUSP by PPM1G activates p53 response to DNA damage. Mol Cell. 2012; 45(6):801-813. DOI: 10.1016/j.molcel.2012.01.021 [PubMed: 22361354]

119. Xu K, Wang L, Feng W, Feng Y, Shu HK. Phosphatidylinositol-3 kinase-dependent translational regulation of Id1 involves the PPM1G phosphatase. Oncogene. 2016; 35(44):5807-5816. DOI: 10.1038/onc.2016.115 [PubMed: 27065332]

120. Liu J, Stevens PD, Gao T. mTOR-dependent regulation of PHLPP expression controls the rapamycin sensitivity in cancer cells. J Biol Chem. 2011; 286(8):6510-6520. DOI: 10.1074/ jbc.M110.183087 [PubMed: 21177869]

121. Cragg MS, Harris C, Strasser A, Scott CL. Unleashing the power of inhibitors of oncogenic kinases through BH3 mimetics. Nat Rev Cancer. 2009; 9(5):321-326. DOI: 10.1038/nrc2615 [PubMed: 19343035]

122. Kelly GL, Strasser A. The essential role of evasion from cell death in cancer. Adv Cancer Res. 2011; 111:39-96. DOI: 10.1016/B978-0-12-385524-4.00002-7 [PubMed: 21704830]

123. Brentnall M, Rodriguez-Menocal L, De Guevara RL, Cepero E, Boise LH. Caspase-9, caspase-3 and caspase-7 have distinct roles during intrinsic apoptosis. BMC Cell Biol. 2013; 14:32.doi: 10.1186/1471-2121-14-32 [PubMed: 23834359] 
124. Shamas-Din A, Brahmbhatt H, Leber B, Andrews DW. BH3-only proteins: Orchestrators of apoptosis. Biochim Biophys Acta. 2011; 1813(4):508-520. DOI: 10.1016/j.bbamcr.2010.11.024 [PubMed: 21146563]

125. Czabotar PE, Lessene G, Strasser A, Adams JM. Control of apoptosis by the BCL-2 protein family: implications for physiology and therapy. Nat Rev Mol Cell Biol. 2014; 15(1):49-63. DOI: 10.1038/nrm3722 [PubMed: 24355989]

126. Kim J, Parrish AB, Kurokawa M, Matsuura K, Freel CD, Andersen JL, Johnson CE, Kornbluth S. Rsk-mediated phosphorylation and 14-3-3varepsilon binding of Apaf-1 suppresses cytochrome cinduced apoptosis. EMBO J. 2012; 31(5):1279-1292. DOI: 10.1038/emboj.2011.491 [PubMed: 22246185]

127. Serrano BP, Szydlo HS, Alfandari DR, Hardy JA. Active-site adjacent phosphorylation at Tyr-397 by c-Abl kinase inactivates caspase-9. J Biol Chem. 2017; doi: 10.1074/jbc.M117.811976

128. Raina D, Pandey P, Ahmad R, Bharti A, Ren J, Kharbanda S, Weichselbaum R, Kufe D. c-Abl tyrosine kinase regulates caspase-9 autocleavage in the apoptotic response to DNA damage. J Biol Chem. 2005; 280(12):11147-11151. DOI: 10.1074/jbc.M413787200 [PubMed: 15657060]

129. Allan LA, Morrice N, Brady S, Magee G, Pathak S, Clarke PR. Inhibition of caspase-9 through phosphorylation at Thr 125 by ERK MAPK. Nat Cell Biol. 2003; 5(7):647-654. DOI: 10.1038/ ncb1005 [PubMed: 12792650]

130. Dessauge F, Cayla X, Albar JP, Fleischer A, Ghadiri A, Duhamel M, Rebollo A. Identification of PP1alpha as a caspase-9 regulator in IL-2 deprivation-induced apoptosis. J Immunol. 2006; 177(4):2441-2451. [PubMed: 16888006]

131. Lowman XH, McDonnell MA, Kosloske A, Odumade OA, Jenness C, Karim CB, Jemmerson R, Kelekar A. The proapoptotic function of Noxa in human leukemia cells is regulated by the kinase Cdk5 and by glucose. Mol Cell. 2010; 40(5):823-833. DOI: 10.1016/j.molcel.2010.11.035 [PubMed: 21145489]

132. Karim CB, Espinoza-Fonseca LM, James ZM, Hanse EA, Gaynes JS, Thomas DD, Kelekar A. Structural Mechanism for Regulation of Bcl-2 protein Noxa by phosphorylation. Sci Rep. 2015; 5:14557.doi: 10.1038/srep14557 [PubMed: 26411306]

133. Shao Y, Aplin AE. ERK2 phosphorylation of serine 77 regulates Bmf pro-apoptotic activity. Cell Death Dis. 2012; 3:e253.doi: 10.1038/cddis.2011.137 [PubMed: 22258404]

134. Fricker M, O’Prey J, Tolkovsky AM, Ryan KM. Phosphorylation of Puma modulates its apoptotic function by regulating protein stability. Cell Death Dis. 2010; 1:e59.doi: 10.1038/cddis.2010.38 [PubMed: 21364664]

135. Ley R, Balmanno K, Hadfield K, Weston C, Cook SJ. Activation of the ERK1/2 signaling pathway promotes phosphorylation and proteasome-dependent degradation of the $\mathrm{BH} 3$-only protein, Bim. J Biol Chem. 2003; 278(21):18811-18816. DOI: 10.1074/jbc.M301010200 [PubMed: 12646560]

136. Li YM, Wen Y, Zhou BP, Kuo HP, Ding Q, Hung MC. Enhancement of Bik antitumor effect by Bik mutants. Cancer Res. 2003; 63(22):7630-7633. [PubMed: 14633680]

137. Verma S, Zhao LJ, Chinnadurai G. Phosphorylation of the pro-apoptotic protein BIK: mapping of phosphorylation sites and effect on apoptosis. J Biol Chem. 2001; 276(7):4671-4676. DOI: 10.1074/jbc.M008983200 [PubMed: 11084041]

138. Kutuk O, Letai A. Regulation of Bcl-2 family proteins by posttranslational modifications. Curr Mol Med. 2008; 8(2):102-118. [PubMed: 18336291]

139. Chiang CW, Harris G, Ellig C, Masters SC, Subramanian R, Shenolikar S, Wadzinski BE, Yang E. Protein phosphatase $2 \mathrm{~A}$ activates the proapoptotic function of BAD in interleukin- 3dependent lymphoid cells by a mechanism requiring 14-3-3 dissociation. Blood. 2001; 97(5): 1289-1297. [PubMed: 11222372]

140. Klumpp S, Selke D, Krieglstein J. Protein phosphatase type 2C dephosphorylates BAD. Neurochem Int. 2003; 42(7):555-560. [PubMed: 12590938]

141. Ayllon V, Martinez AC, Garcia A, Cayla X, Rebollo A. Protein phosphatase 1alpha is a Rasactivated Bad phosphatase that regulates interleukin-2 deprivation-induced apoptosis. EMBO J. 2000; 19(10):2237-2246. DOI: 10.1093/emboj/19.10.2237 [PubMed: 10811615] 
142. Wang HG, Pathan N, Ethell IM, Krajewski S, Yamaguchi Y, Shibasaki F, McKeon F, Bobo T, Franke TF, Reed JC. Ca2+-induced apoptosis through calcineurin dephosphorylation of BAD. Science. 1999; 284(5412):339-343. [PubMed: 10195903]

143. Polzien L, Baljuls A, Rennefahrt UE, Fischer A, Schmitz W, Zahedi RP, Sickmann A, Metz R, Albert S, Benz R, Hekman M, Rapp UR. Identification of novel in vivo phosphorylation sites of the human proapoptotic protein BAD: pore-forming activity of BAD is regulated by phosphorylation. J Biol Chem. 2009; 284(41):28004-28020. DOI: 10.1074/jbc.M109.010702 [PubMed: 19667065]

144. Correia C, Lee SH, Meng XW, Vincelette ND, Knorr KL, Ding H, Nowakowski GS, Dai H, Kaufmann SH. Emerging understanding of Bcl-2 biology: Implications for neoplastic progression and treatment. Biochim Biophys Acta. 2015; 1853(7):1658-1671. DOI: 10.1016/ j.bbamcr.2015.03.012 [PubMed: 25827952]

145. Ruvolo PP, Clark W, Mumby M, Gao F, May WS. A functional role for the B56 alpha-subunit of protein phosphatase $2 \mathrm{~A}$ in ceramide-mediated regulation of $\mathrm{Bcl} 2$ phosphorylation status and function. J Biol Chem. 2002; 277(25):22847-22852. DOI: 10.1074/jbc.M201830200 [PubMed: 11929874]

146. Low IC, Loh T, Huang Y, Virshup DM, Pervaiz S. Ser70 phosphorylation of Bcl-2 by selective tyrosine nitration of PP2A-B56delta stabilizes its antiapoptotic activity. Blood. 2014; 124(14): 2223-2234. DOI: 10.1182/blood-2014-03-563296 [PubMed: 25082878]

147. Ishikawa Y, Kusaka E, Enokido Y, Ikeuchi T, Hatanaka H. Regulation of Bax translocation through phosphorylation at Ser-70 of Bcl-2 by MAP kinase in NO-induced neuronal apoptosis. Mol Cell Neurosci. 2003; 24(2):451-459. [PubMed: 14572466]

148. Wei Y, Pattingre S, Sinha S, Bassik M, Levine B. JNK1-mediated phosphorylation of Bcl-2 regulates starvation-induced autophagy. Mol Cell. 2008; 30(6):678-688. DOI: 10.1016/j.molcel. 2008.06.001 [PubMed: 18570871]

149. Haldar S, Chintapalli J, Croce CM. Taxol induces bcl-2 phosphorylation and death of prostate cancer cells. Cancer Res. 1996; 56(6):1253-1255. [PubMed: 8640809]

150. Poruchynsky MS, Wang EE, Rudin CM, Blagosklonny MV, Fojo T. Bcl-xL is phosphorylated in malignant cells following microtubule disruption. Cancer Res. 1998; 58(15):3331-3338. [PubMed: 9699663]

151. Upreti M, Galitovskaya EN, Chu R, Tackett AJ, Terrano DT, Granell S, Chambers TC. Identification of the major phosphorylation site in Bcl-xL induced by microtubule inhibitors and analysis of its functional significance. J Biol Chem. 2008; 283(51):35517-35525. DOI: 10.1074/ jbc.M805019200 [PubMed: 18974096]

152. Sakurikar N, Eichhorn JM, Chambers TC. Cyclin-dependent kinase-1 (Cdk1)/cyclin B1 dictates cell fate after mitotic arrest via phosphoregulation of antiapoptotic Bcl-2 proteins. J Biol Chem. 2012; 287(46):39193-39204. DOI: 10.1074/jbc.M112.391854 [PubMed: 22965228]

153. Eichhorn JM, Sakurikar N, Alford SE, Chu R, Chambers TC. Critical role of anti-apoptotic Bcl-2 protein phosphorylation in mitotic death. Cell Death Dis. 2013; 4:e834.doi: 10.1038/cddis. 2013.360 [PubMed: 24091677]

154. Haschka MD, Soratroi C, Kirschnek S, Hacker G, Hilbe R, Geley S, Villunger A, Fava LL. The NOXA-MCL1-BIM axis defines lifespan on extended mitotic arrest. Nat Commun. 2015; 6:6891.doi: 10.1038/ncomms7891 [PubMed: 25922916]

155. Schmitt E, Beauchemin M, Bertrand R. Nuclear colocalization and interaction between bcl-xL and cdk1(cdc2) during G2/M cell-cycle checkpoint. Oncogene. 2007; 26(40):5851-5865. DOI: 10.1038/sj.onc.1210396 [PubMed: 17369848]

156. Dai H, Ding H, Meng XW, Lee SH, Schneider PA, Kaufmann SH. Contribution of Bcl-2 phosphorylation to Bak binding and drug resistance. Cancer Res. 2013; 73(23):6998-7008. DOI: 10.1158/0008-5472.CAN-13-0940 [PubMed: 24097825]

157. Yamamoto K, Ichijo H, Korsmeyer SJ. BCL-2 is phosphorylated and inactivated by an ASK1/Jun $\mathrm{N}$-terminal protein kinase pathway normally activated at G(2)/M. Mol Cell Biol. 1999; 19(12): 8469-8478. [PubMed: 10567572]

158. Antony R, Lukiw WJ, Bazan NG. Neuroprotectin D1 induces dephosphorylation of Bcl-xL in a PP2A-dependent manner during oxidative stress and promotes retinal pigment epithelial cell 
survival. J Biol Chem. 2010; 285(24):18301-18308. DOI: 10.1074/jbc.M109.095232 [PubMed: 20363734]

159. Basu A, Haldar S. Identification of a novel Bcl-xL phosphorylation site regulating the sensitivity of taxol- or 2-methoxyestradiol-induced apoptosis. FEBS Lett. 2003; 538(1-3):41-47. [PubMed: 12633850]

160. Nifoussi SK, Ratcliffe NR, Ornstein DL, Kasof G, Strack S, Craig RW. Inhibition of protein phosphatase 2A (PP2A) prevents Mcl-1 protein dephosphorylation at the Thr-163/Ser-159 phosphodegron, dramatically reducing expression in Mcl-1-amplified lymphoma cells. J Biol Chem. 2014; 289(32):21950-21959. DOI: 10.1074/jbc.M114.587873 [PubMed: 24939844]

161. Kajihara R, Sakamoto H, Tanabe K, Takemoto K, Tasaki M, Ando Y, Inui S. Protein phosphatase 6 controls BCR-induced apoptosis of WEHI-231 cells by regulating ubiquitination of Bcl-xL. J Immunol. 2014; 192(12):5720-5729. DOI: 10.4049/jimmunol.1302643 [PubMed: 24808369]

162. Ayllon V, Cayla X, Garcia A, Fleischer A, Rebollo A. The anti-apoptotic molecules Bcl-xL and Bcl-w target protein phosphatase 1alpha to Bad. Eur J Immunol. 2002; 32(7):1847-1855. DOI: 10.1002/1521-4141(200207)32:7<1847::AID-IMMU1847>3.0.CO;2-7 [PubMed: 12115603]

163. Xin M, Deng X. Protein phosphatase 2A enhances the proapoptotic function of Bax through dephosphorylation. J Biol Chem. 2006; 281(27):18859-18867. DOI: 10.1074/jbc.M512543200 [PubMed: 16679323]

164. Puthalakath H, O'Reilly LA, Gunn P, Lee L, Kelly PN, Huntington ND, Hughes PD, Michalak EM, McKimm-Breschkin J, Motoyama N, Gotoh T, Akira S, Bouillet P, Strasser A. ER stress triggers apoptosis by activating BH3-only protein Bim. Cell. 2007; 129(7):1337-1349. DOI: 10.1016/j.cell.2007.04.027 [PubMed: 17604722]

165. Kiyota M, Kuroda J, Yamamoto-Sugitani M, Shimura Y, Nakayama R, Nagoshi H, Mizutani S, Chinen Y, Sasaki N, Sakamoto N, Kobayashi T, Matsumoto Y, Horiike S, Taniwaki M. FTY720 induces apoptosis of chronic myelogenous leukemia cells via dual activation of BIM and BID and overcomes various types of resistance to tyrosine kinase inhibitors. Apoptosis. 2013; 18(11): 1437-1446. DOI: 10.1007/s10495-013-0882-y [PubMed: 23851982]

166. Lin CF, Chen CL, Chiang CW, Jan MS, Huang WC, Lin YS. GSK-3beta acts downstream of PP2A and the PI 3-kinase-Akt pathway, and upstream of caspase-2 in ceramide-induced mitochondrial apoptosis. J Cell Sci. 2007; 120(Pt 16):2935-2943. DOI: 10.1242/jcs.03473 [PubMed: 17666435]

167. Thomas LW, Lam C, Edwards SW. Mcl-1; the molecular regulation of protein function. FEBS Lett. 2010; 584(14):2981-2989. DOI: 10.1016/j.febslet.2010.05.061 [PubMed: 20540941]

168. Kobayashi S, Lee SH, Meng XW, Mott JL, Bronk SF, Werneburg NW, Craig RW, Kaufmann SH, Gores GJ. Serine 64 phosphorylation enhances the antiapoptotic function of Mcl-1. J Biol Chem. 2007; 282(25):18407-18417. DOI: 10.1074/jbc.M610010200 [PubMed: 17463001]

169. Maurer U, Charvet C, Wagman AS, Dejardin E, Green DR. Glycogen synthase kinase-3 regulates mitochondrial outer membrane permeabilization and apoptosis by destabilization of MCL-1. Mol Cell. 2006; 21(6):749-760. DOI: 10.1016/j.molcel.2006.02.009 [PubMed: 16543145]

170. Ding Q, He X, Hsu JM, Xia W, Chen CT, Li LY, Lee DF, Liu JC, Zhong Q, Wang X, Hung MC. Degradation of Mcl-1 by beta-TrCP mediates glycogen synthase kinase 3-induced tumor suppression and chemosensitization. Mol Cell Biol. 2007; 27(11):4006-4017. DOI: 10.1128/ MCB.00620-06 [PubMed: 17387146]

171. Mojsa B, Lassot I, Desagher S. Mcl-1 ubiquitination: unique regulation of an essential survival protein. Cells. 2014; 3(2):418-437. DOI: 10.3390/cells3020418 [PubMed: 24814761]

172. Liu Q, Zhao X, Frissora F, Ma Y, Santhanam R, Jarjoura D, Lehman A, Perrotti D, Chen CS, Dalton JT, Muthusamy N, Byrd JC. FTY720 demonstrates promising preclinical activity for chronic lymphocytic leukemia and lymphoblastic leukemia/lymphoma. Blood. 2008; 111(1): 275-284. DOI: 10.1182/blood-2006-10-053884 [PubMed: 17761520]

173. Christensen DJ, Chen Y, Oddo J, Matta KM, Neil J, Davis ED, Volkheimer AD, Lanasa MC, Friedman DR, Goodman BK, Gockerman JP, Diehl LF, de Castro CM, Moore JO, Vitek MP, Weinberg JB. SET oncoprotein overexpression in B-cell chronic lymphocytic leukemia and nonHodgkin lymphoma: a predictor of aggressive disease and a new treatment target. Blood. 2011; 118(15):4150-4158. DOI: 10.1182/blood-2011-04-351072 [PubMed: 21844565] 
174. Wang CY, Lin YS, Su WC, Chen CL, Lin CF. Glycogen synthase kinase-3 and Omi/HtrA2 induce annexin A2 cleavage followed by cell cycle inhibition and apoptosis. Mol Biol Cell. 2009; 20(19):4153-4161. DOI: 10.1091/mbc.E09-02-0174 [PubMed: 19656851]

175. Nica AF, Tsao CC, Watt JC, Jiffar T, Kurinna S, Jurasz P, Konopleva M, Andreeff M, Radomski MW, Ruvolo PP. Ceramide promotes apoptosis in chronic myelogenous leukemia-derived K562 cells by a mechanism involving caspase-8 and JNK. Cell Cycle. 2008; 7(21):3362-3370. DOI: 10.4161/cc.7.21.6894 [PubMed: 18948750]

176. Morad SA, Cabot MC. Ceramide-orchestrated signalling in cancer cells. Nat Rev Cancer. 2013; 13(1):51-65. DOI: 10.1038/nrc3398 [PubMed: 23235911]

177. Desagher S, Osen-Sand A, Montessuit S, Magnenat E, Vilbois F, Hochmann A, Journot L, Antonsson B, Martinou JC. Phosphorylation of bid by casein kinases I and II regulates its cleavage by caspase 8 . Mol Cell. 2001; 8(3):601-611. [PubMed: 11583622]

178. Hellwig CT, Ludwig-Galezowska AH, Concannon CG, Litchfield DW, Prehn JH, Rehm M. Activity of protein kinase CK2 uncouples Bid cleavage from caspase- 8 activation. J Cell Sci. 2010; 123(Pt 9):1401-1406. DOI: 10.1242/jcs.061143 [PubMed: 20356928]

179. Yuan XJ, Whang YE. PTEN sensitizes prostate cancer cells to death receptor-mediated and druginduced apoptosis through a FADD-dependent pathway. Oncogene. 2002; 21(2):319-327. DOI: 10.1038/sj.onc.1205054 [PubMed: 11803475]

180. Chakrabandhu K, Huault S, Durivault J, Lang K, Ta Ngoc L, Bole A, Doma E, Derijard B, Gerard JP, Pierres M, Hueber AO. An Evolution-Guided Analysis Reveals a Multi-Signaling Regulation of Fas by Tyrosine Phosphorylation and its Implication in Human Cancers. PLoS Biol. 2016; 14(3):e1002401.doi: 10.1371/journal.pbio.1002401 [PubMed: 26942442]

181. Jia SH, Parodo J, Kapus A, Rotstein OD, Marshall JC. Dynamic regulation of neutrophil survival through tyrosine phosphorylation or dephosphorylation of caspase-8. J Biol Chem. 2008; 283(9): 5402-5413. DOI: 10.1074/jbc.M706462200 [PubMed: 18086677]

182. Gloire G, Charlier E, Piette J. Regulation of CD95/APO-1/Fas-induced apoptosis by protein phosphatases. Biochem Pharmacol. 2008; 76(11):1451-1458. DOI: 10.1016/j.bcp.2008.06.023 [PubMed: 18656456]

183. Foehr ED, Lorente G, Vincent V, Nikolich K, Urfer R. FAS associated phosphatase (FAP-1) blocks apoptosis of astrocytomas through dephosphorylation of FAS. J Neurooncol. 2005; 74(3): 241-248. DOI: 10.1007/s11060-004-7202-x [PubMed: 16187021]

184. Ivanov VN, Lopez Bergami P, Maulit G, Sato TA, Sassoon D, Ronai Z. FAP-1 association with Fas (Apo-1) inhibits Fas expression on the cell surface. Mol Cell Biol. 2003; 23(10):3623-3635. [PubMed: 12724420]

185. He RJ, Yu ZH, Zhang RY, Zhang ZY. Protein tyrosine phosphatases as potential therapeutic targets. Acta Pharmacol Sin. 2014; 35(10):1227-1246. DOI: 10.1038/aps.2014.80 [PubMed: 25220640]

186. Ivanov VN, Ronai Z, Hei TK. Opposite roles of FAP-1 and dynamin in the regulation of Fas (CD95) translocation to the cell surface and susceptibility to Fas ligand-mediated apoptosis. J Biol Chem. 2006; 281(3):1840-1852. DOI: 10.1074/jbc.M509866200 [PubMed: 16306044]

187. Wieckowski E, Atarashi Y, Stanson J, Sato TA, Whiteside TL. FAP-1-mediated activation of NFkappaB induces resistance of head and neck cancer to Fas-induced apoptosis. J Cell Biochem. 2007; 100(1):16-28. DOI: 10.1002/jcb.20922 [PubMed: 16888780]

188. Srikanth S, Franklin CC, Duke RC, Kraft RS. Human DU145 prostate cancer cells overexpressing mitogen-activated protein kinase phosphatase-1 are resistant to Fas ligand-induced mitochondrial perturbations and cellular apoptosis. Mol Cell Biochem. 1999; 199(1-2):169-178. [PubMed: 10544965]

189. Harmala-Brasken AS, Mikhailov A, Soderstrom TS, Meinander A, Holmstrom TH, Damuni Z, Eriksson JE. Type-2A protein phosphatase activity is required to maintain death receptor responsiveness. Oncogene. 2003; 22(48):7677-7686. DOI: 10.1038/sj.onc.1207077 [PubMed: 14576831]

190. Alvarado-Kristensson M, Andersson T. Protein phosphatase 2A regulates apoptosis in neutrophils by dephosphorylating both p38 MAPK and its substrate caspase 3. J Biol Chem. 2005; 280(7): 6238-6244. DOI: 10.1074/jbc.M409718200 [PubMed: 15569672] 
191. Chatfield K, Eastman A. Inhibitors of protein phosphatases 1 and $2 \mathrm{~A}$ differentially prevent intrinsic and extrinsic apoptosis pathways. Biochem Biophys Res Commun. 2004; 323(4):13131320. DOI: 10.1016/j.bbrc.2004.09.003 [PubMed: 15451440]

192. Dillon LM, Miller TW. Therapeutic targeting of cancers with loss of PTEN function. Curr Drug Targets. 2014; 15(1):65-79. [PubMed: 24387334]

193. Sangodkar J, Perl A, Tohme R, Kiselar J, Kastrinsky DB, Zaware N, Izadmehr S, Mazhar S, Wiredja DD, O'Connor CM, Hoon D, Dhawan NS, Schlatzer D, Yao S, Leonard D, Borczuk AC, Gokulrangan G, Wang L, Svenson E, Farrington CC, Yuan E, Avelar RA, Stachnik A, Smith B, Gidwani V, Giannini HM, McQuaid D, McClinch K, Wang Z, Levine AC, Sears RC, Chen EY, Duan Q, Datt M, Haider S, Ma'ayan A, DiFeo A, Sharma N, Galsky MD, Brautigan DL, Ioannou YA, Xu W, Chance MR, Ohlmeyer M, Narla G. Activation of tumor suppressor protein PP2A inhibits KRAS-driven tumor growth. J Clin Invest. 2017; 127(6):2081-2090. DOI: 10.1172/ JCI89548 [PubMed: 28504649]

194. Neviani P, Santhanam R, Oaks JJ, Eiring AM, Notari M, Blaser BW, Liu S, Trotta R, Muthusamy N, Gambacorti-Passerini C, Druker BJ, Cortes J, Marcucci G, Chen CS, Verrills NM, Roy DC, Caligiuri MA, Bloomfield CD, Byrd JC, Perrotti D. FTY720, a new alternative for treating blast crisis chronic myelogenous leukemia and Philadelphia chromosome-positive acute lymphocytic leukemia. J Clin Invest. 2007; 117(9):2408-2421. DOI: 10.1172/JCI31095 [PubMed: 17717597]

195. Agarwal A, MacKenzie RJ, Pippa R, Eide CA, Oddo J, Tyner JW, Sears R, Vitek MP, Odero MD, Christensen DJ, Druker BJ. Antagonism of SET using OP449 enhances the efficacy of tyrosine kinase inhibitors and overcomes drug resistance in myeloid leukemia. Clin Cancer Res. 2014; 20(8):2092-2103. DOI: 10.1158/1078-0432.CCR-13-2575 [PubMed: 24436473]

196. Bollu LR, Mazumdar A, Savage MI, Brown PH. Molecular Pathways: Targeting Protein Tyrosine Phosphatases in Cancer. Clin Cancer Res. 2017; 23(9):2136-2142. DOI: 10.1158/1078-0432.CCR-16-0934 [PubMed: 28087641]

197. Hong CS, Ho W, Zhang C, Yang C, Elder JB, Zhuang Z. LB100, a small molecule inhibitor of PP2A with potent chemo- and radio-sensitizing potential. Cancer Biol Ther. 2015; 16(6):821833. DOI: 10.1080/15384047.2015.1040961 [PubMed: 25897893]

198. O’Connor CM, Perl A, Leonard D, Sangodkar J, Narla G. Therapeutic Targeting of PP2A. Int J Biochem Cell Biol. 2017; doi: 10.1016/j.biocel.2017.10.008

199. Ramaswamy K, Spitzer B, Kentsis A. Therapeutic Re-Activation of Protein Phosphatase 2A in Acute Myeloid Leukemia. Front Oncol. 2015; 5:16.doi: 10.3389/fonc.2015.00016 [PubMed: 25699237]

200. Carratu MR, Signorile A, De Rasmo D, Reale A, Vacca A. Pharmacological Activation of Protein Phosphatase 2 A (PP2A): A Novel Strategy to Fight Against Human Malignancies? Curr Med Chem. 2016; 23(38):4286-4296. [PubMed: 27758717]

201. Arriazu E, Pippa R, Odero MD. Protein Phosphatase 2A as a Therapeutic Target in Acute Myeloid Leukemia. Front Oncol. 2016; 6:78.doi: 10.3389/fonc.2016.00078 [PubMed: 27092295]

202. Zhang C, Peng Y, Wang F, Tan X, Liu N, Fan S, Wang D, Zhang L, Liu D, Wang T, Wang S, Zhou Y, Su Y, Cheng T, Zhuang Z, Shi C. A synthetic cantharidin analog for the enhancement of doxorubicin suppression of stem cell-derived aggressive sarcoma. Biomaterials. 2010; 31(36): 9535-9543. DOI: 10.1016/j.biomaterials.2010.08.059 [PubMed: 20875681]

203. Nguyen LK, Matallanas D, Croucher DR, von Kriegsheim A, Kholodenko BN. Signalling by protein phosphatases and drug development: a systems-centred view. FEBS J. 2013; 280(2):751765. DOI: 10.1111/j.1742-4658.2012.08522.x [PubMed: 22340367]

204. Behjati S, Tarpey PS, Sheldon H, Martincorena I, Van Loo P, Gundem G, Wedge DC, Ramakrishna M, Cooke SL, Pillay N, Vollan HKM, Papaemmanuil E, Koss H, Bunney TD, Hardy C, Joseph OR, Martin S, Mudie L, Butler A, Teague JW, Patil M, Steers G, Cao Y, Gumbs C, Ingram D, Lazar AJ, Little L, Mahadeshwar H, Protopopov A, Al Sannaa GA, Seth S, Song X, Tang J, Zhang J, Ravi V, Torres KE, Khatri B, Halai D, Roxanis I, Baumhoer D, Tirabosco R, Amary MF, Boshoff C, McDermott U, Katan M, Stratton MR, Futreal PA, Flanagan AM, Harris A, Campbell PJ. Recurrent PTPRB and PLCG1 mutations in angiosarcoma. Nat Genet. 2014; 46(4):376-379. DOI: 10.1038/ng.2921 [PubMed: 24633157] 
205. Qi Y, Dai Y, Gui S. Protein tyrosine phosphatase PTPRB regulates Src phosphorylation and tumour progression in NSCLC. Clin Exp Pharmacol Physiol. 2016; 43(10):1004-1012. DOI: 10.1111/1440-1681.12610 [PubMed: 27314562]

206. Munkley J, Lafferty NP, Kalna G, Robson CN, Leung HY, Rajan P, Elliott DJ. Androgenregulation of the protein tyrosine phosphatase PTPRR activates ERK1/2 signalling in prostate cancer cells. BMC Cancer. 2015; 15:9.doi: 10.1186/s12885-015-1012-8 [PubMed: 25592066]

207. Su PH, Lin YW, Huang RL, Liao YP, Lee HY, Wang HC, Chao TK, Chen CK, Chan MW, Chu TY, Yu MH, Lai HC. Epigenetic silencing of PTPRR activates MAPK signaling, promotes metastasis and serves as a biomarker of invasive cervical cancer. Oncogene. 2013 ; 32(1):15-26. DOI: 10.1038/onc.2012.29 [PubMed: 22330137]

208. Suarez Pestana E, Tenev T, Gross S, Stoyanov B, Ogata M, Bohmer FD. The transmembrane protein tyrosine phosphatase RPTPsigma modulates signaling of the epidermal growth factor receptor in A431 cells. Oncogene. 1999; 18(28):4069-4079. DOI: 10.1038/sj.onc.1202794 [PubMed: 10435588]

209. Morris LG, Taylor BS, Bivona TG, Gong Y, Eng S, Brennan CW, Kaufman A, Kastenhuber ER, Banuchi VE, Singh B, Heguy A, Viale A, Mellinghoff IK, Huse J, Ganly I, Chan TA. Genomic dissection of the epidermal growth factor receptor (EGFR)/PI3K pathway reveals frequent deletion of the EGFR phosphatase PTPRS in head and neck cancers. Proc Natl Acad Sci U S A. 2011; 108(47):19024-19029. DOI: 10.1073/pnas.1111963108 [PubMed: 22065749]

210. Wang Z, Shen D, Parsons DW, Bardelli A, Sager J, Szabo S, Ptak J, Silliman N, Peters BA, van der Heijden MS, Parmigiani G, Yan H, Wang TL, Riggins G, Powell SM, Willson JK, Markowitz S, Kinzler KW, Vogelstein B, Velculescu VE. Mutational analysis of the tyrosine phosphatome in colorectal cancers. Science. 2004; 304(5674):1164-1166. DOI: 10.1126/science.1096096 [PubMed: 15155950]

211. Elson A, Leder P. Protein-tyrosine phosphatase epsilon. An isoform specifically expressed in mouse mammary tumors initiated by v-Ha-ras OR neu. J Biol Chem. 1995; 270(44):2611626122. [PubMed: 7592814]

212. Gil-Henn H, Elson A. Tyrosine phosphatase-epsilon activates Src and supports the transformed phenotype of Neu-induced mammary tumor cells. J Biol Chem. 2003; 278(18):15579-15586. DOI: 10.1074/jbc.M210273200 [PubMed: 12598528]

213. Sadakata H, Okazawa H, Sato T, Supriatna Y, Ohnishi H, Kusakari S, Murata Y, Ito T, Nishiyama U, Minegishi T, Harada A, Matozaki T. SAP-1 is a microvillus-specific protein tyrosine phosphatase that modulates intestinal tumorigenesis. Genes Cells. 2009; 14(3):295-308. DOI: 10.1111/j.1365-2443.2008.01270.x [PubMed: 19170756]

214. Seo Y, Matozaki T, Tsuda M, Hayashi Y, Itoh H, Kasuga M. Overexpression of SAP-1, a transmembrane-type protein tyrosine phosphatase, in human colorectal cancers. Biochem Biophys Res Commun. 1997; 231(3):705-711. DOI: 10.1006/bbrc.1997.6139 [PubMed: 9070877]

215. Xu H, Cai T, Carmona GN, Abuhatzira L, Notkins AL. Small cell lung cancer growth is inhibited by miR-342 through its effect of the target gene IA-2. J Transl Med. 2016; 14(1):278.doi: 10.1186/s12967-016-1036-0 [PubMed: 27670444]

216. Sengelaub CA, Navrazhina K, Ross JB, Halberg N, Tavazoie SF. PTPRN2 and PLCbeta1 promote metastatic breast cancer cell migration through PI(4,5)P2-dependent actin remodeling. EMBO J. 2016; 35(1):62-76. DOI: 10.15252/embj.201591973 [PubMed: 26620550]

217. Sorokin AV, Nair BC, Wei Y, Aziz KE, Evdokimova V, Hung MC, Chen J. Aberrant Expression of proPTPRN2 in Cancer Cells Confers Resistance to Apoptosis. Cancer Res. 2015; 75(9):18461858. DOI: 10.1158/0008-5472.CAN-14-2718 [PubMed: 25877877]

218. Spring K, Fournier P, Lapointe L, Chabot C, Roussy J, Pommey S, Stagg J, Royal I. The protein tyrosine phosphatase DEP-1/PTPRJ promotes breast cancer cell invasion and metastasis. Oncogene. 2015; 34(44):5536-5547. DOI: 10.1038/onc.2015.9 [PubMed: 25772245]

219. Sun PH, Ye L, Mason MD, Jiang WG. Receptor-like protein tyrosine phosphatase kappa negatively regulates the apoptosis of prostate cancer cells via the JNK pathway. Int J Oncol. 2013; 43(5):1560-1568. DOI: 10.3892/ijo.2013.2082 [PubMed: 24002526]

220. Novellino L, De Filippo A, Deho P, Perrone F, Pilotti S, Parmiani G, Castelli C. PTPRK negatively regulates transcriptional activity of wild type and mutated oncogenic beta-catenin and 
affects membrane distribution of beta-catenin/E-cadherin complexes in cancer cells. Cell Signal. 2008; 20(5):872-883. DOI: 10.1016/j.cellsig.2007.12.024 [PubMed: 18276111]

221. Chen YW, Guo T, Shen L, Wong KY, Tao Q, Choi WW, Au-Yeung RK, Chan YP, Wong ML, Tang JC, Liu WP, Li GD, Shimizu N, Loong F, Tse E, Kwong YL, Srivastava G. Receptor-type tyrosine-protein phosphatase kappa directly targets STAT3 activation for tumor suppression in nasal NK/T-cell lymphoma. Blood. 2015; 125(10):1589-1600. DOI: 10.1182/ blood-2014-07-588970 [PubMed: 25612622]

222. Burgoyne AM, Palomo JM, Phillips-Mason PJ, Burden-Gulley SM, Major DL, Zaremba A, Robinson S, Sloan AE, Vogelbaum MA, Miller RH, Brady-Kalnay SM. PTPmu suppresses glioma cell migration and dispersal. Neuro Oncol. 2009; 11(6):767-778. DOI: 10.1215/15228517-2009-019 [PubMed: 19304959]

223. Burgoyne AM, Phillips-Mason PJ, Burden-Gulley SM, Robinson S, Sloan AE, Miller RH, BradyKalnay SM. Proteolytic cleavage of protein tyrosine phosphatase mu regulates glioblastoma cell migration. Cancer Res. 2009; 69(17):6960-6968. DOI: 10.1158/0008-5472.CAN-09-0863 [PubMed: 19690139]

224. Kaur H, Burden-Gulley SM, Phillips-Mason PJ, Basilion JP, Sloan AE, Brady-Kalnay SM. Protein tyrosine phosphatase mu regulates glioblastoma cell growth and survival in vivo. Neuro Oncol. 2012; 14(5):561-573. DOI: 10.1093/neuonc/nos066 [PubMed: 22505657]

225. Sudhir PR, Lin ST, Chia-Wen C, Yang SH, Li AF, Lai RH, Wang MJ, Chen YT, Chen CF, Jou YS, Chen JY. Loss of PTPRM associates with the pathogenic development of colorectal adenoma-carcinoma sequence. Sci Rep. 2015; 5:9633.doi: 10.1038/srep09633 [PubMed: 25910225]

226. Sun PH, Ye L, Mason MD, Jiang WG. Protein tyrosine phosphatase micro (PTP micro or PTPRM), a negative regulator of proliferation and invasion of breast cancer cells, is associated with disease prognosis. PLoS One. 2012; 7(11):e50183.doi: 10.1371/journal.pone.0050183 [PubMed: 23185569]

227. Yuan T, Wang Y, Zhao ZJ, Gu H. Protein-tyrosine phosphatase PTPN9 negatively regulates ErbB2 and epidermal growth factor receptor signaling in breast cancer cells. J Biol Chem. 2010; 285(20):14861-14870. DOI: 10.1074/jbc.M109.099879 [PubMed: 20335174]

228. Kodama T, Newberg JY, Kodama M, Rangel R, Yoshihara K, Tien JC, Parsons PH, Wu H, Finegold MJ, Copeland NG, Jenkins NA. Transposon mutagenesis identifies genes and cellular processes driving epithelial-mesenchymal transition in hepatocellular carcinoma. Proc Natl Acad Sci U S A. 2016; 113(24):E3384-3393. DOI: 10.1073/pnas.1606876113 [PubMed: 27247392]

229. Li J, Davidson D, Martins Souza C, Zhong MC, Wu N, Park M, Muller WJ, Veillette A. Loss of PTPN12 Stimulates Progression of ErbB2-Dependent Breast Cancer by Enhancing Cell Survival, Migration, and Epithelial-to-Mesenchymal Transition. Mol Cell Biol. 2015; 35(23):4069-4082. DOI: 10.1128/MCB.00741-15 [PubMed: 26391955]

230. Wadham C, Gamble JR, Vadas MA, Khew-Goodall Y. The protein tyrosine phosphatase Pez is a major phosphatase of adherens junctions and dephosphorylates beta-catenin. Mol Biol Cell. 2003; 14(6):2520-2529. DOI: 10.1091/mbc.E02-09-0577 [PubMed: 12808048]

231. Liu X, Yang N, Figel SA, Wilson KE, Morrison CD, Gelman IH, Zhang J. PTPN14 interacts with and negatively regulates the oncogenic function of YAP. Oncogene. 2013; 32(10):1266-1273. DOI: 10.1038/onc.2012.147 [PubMed: 22525271]

232. Carlucci A, Porpora M, Garbi C, Galgani M, Santoriello M, Mascolo M, di Lorenzo D, Altieri V, Quarto M, Terracciano L, Gottesman ME, Insabato L, Feliciello A. PTPD1 supports receptor stability and mitogenic signaling in bladder cancer cells. J Biol Chem. 2010; 285(50):39260 39270. DOI: 10.1074/jbc.M110.174706 [PubMed: 20923765]

233. Lessard L, Stuible M, Tremblay ML. The two faces of PTP1B in cancer. Biochim Biophys Acta. 2010; 1804(3):613-619. DOI: 10.1016/j.bbapap.2009.09.018 [PubMed: 19782770]

234. Zanke B, Squire J, Griesser H, Henry M, Suzuki H, Patterson B, Minden M, Mak TW. A hematopoietic protein tyrosine phosphatase (HePTP) gene that is amplified and overexpressed in myeloid malignancies maps to chromosome 1q32.1. Leukemia. 1994; 8(2):236-244. [PubMed: 8309248] 
235. Gronda M, Arab S, Iafrate B, Suzuki H, Zanke BW. Hematopoietic protein tyrosine phosphatase suppresses extracellular stimulus-regulated kinase activation. Mol Cell Biol. 2001; 21(20):68516858. DOI: 10.1128/MCB.21.20.6851-6858.2001 [PubMed: 11564869]

236. Glondu-Lassis M, Dromard M, Lacroix-Triki M, Nirde P, Puech C, Knani D, Chalbos D, Freiss G. PTPL1/PTPN13 regulates breast cancer cell aggressiveness through direct inactivation of Src kinase. Cancer Res. 2010; 70(12):5116-5126. DOI: 10.1158/0008-5472.CAN-09-4368 [PubMed: 20501847]

237. Yeh SH, Wu DC, Tsai CY, Kuo TJ, Yu WC, Chang YS, Chen CL, Chang CF, Chen DS, Chen PJ. Genetic characterization of fas-associated phosphatase-1 as a putative tumor suppressor gene on chromosome 4q21.3 in hepatocellular carcinoma. Clin Cancer Res. 2006; 12(4):1097-1108. DOI: 10.1158/1078-0432.CCR-05-1383 [PubMed: 16489062]

238. Deng J, Zhang J, Wang C, Wei Q, Zhou D, Zhao K. Methylation and expression of PTPN22 in esophageal squamous cell carcinoma. Oncotarget. 2016; 7(39):64043-64052. DOI: 10.18632/ oncotarget.11581 [PubMed: 27613842]

239. Negro R, Gobessi S, Longo PG, He Y, Zhang ZY, Laurenti L, Efremov DG. Overexpression of the autoimmunity-associated phosphatase PTPN22 promotes survival of antigen-stimulated CLL cells by selectively activating AKT. Blood. 2012; 19(26):6278-6287. DOI: 10.1182/ blood-2012-01-403162

240. Horita Y, Ohashi K, Mukai M, Inoue M, Mizuno K. Suppression of the invasive capacity of rat ascites hepatoma cells by knockdown of Slingshot or LIM kinase. J Biol Chem. 2008; 283(10): 6013-6021. DOI: 10.1074/jbc.M706538200 [PubMed: 18171679]

241. Wang Y, Kuramitsu Y, Kitagawa T, Baron B, Yoshino S, Maehara S, Maehara Y, Oka M, Nakamura K. Cofilin-phosphatase slingshot-1L (SSH1L) is over-expressed in pancreatic cancer (PC) and contributes to tumor cell migration. Cancer Lett. 2015; 360(2):171-176. DOI: 10.1016/ j.canlet.2015.02.015 [PubMed: 25684665]

242. Mizuno K. Signaling mechanisms and functional roles of cofilin phosphorylation and dephosphorylation. Cell Signal. 2013; 25(2):457-469. DOI: 10.1016/j.cellsig.2012.11.001 [PubMed: 23153585]

243. Bassermann F, Frescas D, Guardavaccaro D, Busino L, Peschiaroli A, Pagano M. The Cdc14BCdh1-Plk1 axis controls the G2 DNA-damage-response checkpoint. Cell. 2008; 134(2):256-267. DOI: 10.1016/j.cell.2008.05.043 [PubMed: 18662541]

244. Lucci MA, Orlandi R, Triulzi T, Tagliabue E, Balsari A, Villa-Moruzzi E. Expression profile of tyrosine phosphatases in HER2 breast cancer cells and tumors. Cell Oncol. 2010; 32(5-6):361372. DOI: 10.3233/CLO-2010-0520 [PubMed: 20413845]

245. Chen Q, Chen K, Guo G, Li F, Chen C, Wang S, Nalepa G, Huang S, Chen JL. A critical role of CDKN3 in Bcr-Abl-mediated tumorigenesis. PLoS One. 2014; 9(10):e111611.doi: 10.1371/ journal.pone.0111611 [PubMed: 25360622]

246. Nalepa G, Barnholtz-Sloan J, Enzor R, Dey D, He Y, Gehlhausen JR, Lehmann AS, Park SJ, Yang Y, Yang X, Chen S, Guan X, Chen Y, Renbarger J, Yang FC, Parada LF, Clapp W. The tumor suppressor CDKN3 controls mitosis. J Cell Biol. 2013; 201(7):997-1012. DOI: 10.1083/ jcb.201205125 [PubMed: 23775190]

247. Fan C, Chen L, Huang Q, Shen T, Welsh EA, Teer JK, Cai J, Cress WD, Wu J. Overexpression of major CDKN3 transcripts is associated with poor survival in lung adenocarcinoma. Br J Cancer. 2015; 113(12):1735-1743. DOI: 10.1038/bjc.2015.378 [PubMed: 26554648]

248. Zang X, Chen M, Zhou Y, Xiao G, Xie Y, Wang X. Identifying CDKN3 Gene Expression as a Prognostic Biomarker in Lung Adenocarcinoma via Meta-analysis. Cancer Inform. 2015; 14(Suppl 2):183-191. DOI: 10.4137/CIN.S17287 [PubMed: 26052221]

249. Yin Y, Shen WH. PTEN: a new guardian of the genome. Oncogene. 2008; 27(41):5443-5453. DOI: 10.1038/onc.2008.241 [PubMed: 18794879]

250. Weidner P, Sohn M, Gutting T, Friedrich T, Gaiser T, Magdeburg J, Kienle P, Ruh H, Hopf C, Behrens HM, Rocken C, Hanoch T, Seger R, Ebert MP, Burgermeister E. Myotubularin-related protein 7 inhibits insulin signaling in colorectal cancer. Oncotarget. 2016; 7(31):50490-50506. DOI: 10.18632/oncotarget.10466 [PubMed: 27409167] 
251. Yoo YD, Cho SM, Kim JS, Chang YS, Ahn CM, Kim HJ. The human myotubularin-related protein suppresses the growth of lung carcinoma cells. Oncol Rep. 2004; 12(3):667-671. [PubMed: 15289854]

252. Kuo YZ, Tai YH, Lo HI, Chen YL, Cheng HC, Fang WY, Lin SH, Yang CL, Tsai ST, Wu LW. MiR-99a exerts anti-metastasis through inhibiting myotubularin-related protein 3 expression in oral cancer. Oral Dis. 2014; 20(3):e65-75. DOI: 10.1111/odi.12133 [PubMed: 23731011]

253. Zheng B, Yu X, Chai R. Myotubularin-related phosphatase 3 promotes growth of colorectal cancer cells. Scientific World Journal. 2014; 2014:703804.doi: 10.1155/2014/703804 [PubMed: 25215329]

254. Wang C, Feng Z, Jiang K, Zuo X. Upregulation of MicroRNA-935 Promotes the Malignant Behaviors of Pancreatic Carcinoma PANC-1 Cells via Targeting Inositol Polyphosphate 4Phosphatase Type I Gene (INPP4A) Oncol Res. 2017; 25(4):559-569. DOI: 10.3727/096504016X14759554689565 [PubMed: 27733216]

255. Alho I, Costa L, Bicho M, Coelho C. The role of low-molecular-weight protein tyrosine phosphatase (LMW-PTP ACP1) in oncogenesis. Tumour Biol. 2013; 34(4):1979-1989. DOI: 10.1007/s13277-013-0784-1 [PubMed: 23584899]

256. Boutros R, Lobjois V, Ducommun B. CDC25 phosphatases in cancer cells: key players? Good targets? Nat Rev Cancer. 2007; 7(7):495-507. DOI: 10.1038/nrc2169 [PubMed: 17568790]

257. Sur S, Agrawal DK. Phosphatases and kinases regulating CDC25 activity in the cell cycle: clinical implications of CDC25 overexpression and potential treatment strategies. Mol Cell Biochem. 2016; 416(1-2):33-46. DOI: 10.1007/s11010-016-2693-2 [PubMed: 27038604]

258. Lee ST, Feng M, Wei Y, Li Z, Qiao Y, Guan P, Jiang X, Wong CH, Huynh K, Wang J, Li J, Karuturi KM, Tan EY, Hoon DS, Kang Y, Yu Q. Protein tyrosine phosphatase UBASH3B is overexpressed in triple-negative breast cancer and promotes invasion and metastasis. Proc Natl Acad Sci U S A. 2013; 110(27):11121-11126. DOI: 10.1073/pnas.1300873110 [PubMed: 23784775]

259. Morita K, Saitoh M, Tobiume K, Matsuura H, Enomoto S, Nishitoh H, Ichijo H. Negative feedback regulation of ASK1 by protein phosphatase 5 (PP5) in response to oxidative stress. EMBO J. 2001; 20(21):6028-6036. DOI: 10.1093/emboj/20.21.6028 [PubMed: 11689443]

260. Luo W, Peterson A, Garcia BA, Coombs G, Kofahl B, Heinrich R, Shabanowitz J, Hunt DF, Yost HJ, Virshup DM. Protein phosphatase 1 regulates assembly and function of the beta-catenin degradation complex. EMBO J. 2007; 26(6):1511-1521. DOI: 10.1038/sj.emboj.7601607 [PubMed: 17318175]

261. Kumar AS, Naruszewicz I, Wang P, Leung-Hagesteijn C, Hannigan GE. ILKAP regulates ILK signaling and inhibits anchorage-independent growth. Oncogene. 2004; 23(19):3454-3461. DOI: 10.1038/sj.onc.1207473 [PubMed: 14990992]

262. Leung-Hagesteijn C, Mahendra A, Naruszewicz I, Hannigan GE. Modulation of integrin signal transduction by ILKAP, a protein phosphatase $2 \mathrm{C}$ associating with the integrin-linked kinase, ILK1. EMBO J. 2001; 20(9):2160-2170. DOI: 10.1093/emboj/20.9.2160 [PubMed: 11331582]

263. Shan C, Kang HB, Elf S, Xie J, Gu TL, Aguiar M, Lonning S, Hitosugi T, Chung TW, Arellano M, Khoury HJ, Shin DM, Khuri FR, Boggon TJ, Fan J. Tyr-94 phosphorylation inhibits pyruvate dehydrogenase phosphatase 1 and promotes tumor growth. J Biol Chem. 2014; 289(31):2141321422. DOI: 10.1074/jbc.M114.581124 [PubMed: 24962578]

264. Prabhu A, Sarcar B, Miller CR, Kim SH, Nakano I, Forsyth P, Chinnaiyan P. Ras-mediated modulation of pyruvate dehydrogenase activity regulates mitochondrial reserve capacity and contributes to glioblastoma tumorigenesis. Neuro Oncol. 2015; 17(9):1220-1230. DOI: 10.1093/ neuonc/nou369 [PubMed: 25712957]

265. Cheng A, Kaldis P, Solomon MJ. Dephosphorylation of human cyclin-dependent kinases by protein phosphatase type 2C alpha and beta 2 isoforms. J Biol Chem. 2000; 275(44):3474434749. DOI: 10.1074/jbc.M006210200 [PubMed: 10934208]

266. Wang H, Chen Y, Han J, Meng Q, Xi Q, Wu G, Zhang B. DCAF4L2 promotes colorectal cancer invasion and metastasis via mediating degradation of NFkappab negative regulator PPM1B. Am J Transl Res. 2016; 8(2):405-418. [PubMed: 27158335] 
267. Geng J, Fan J, Ouyang Q, Zhang X, Zhang X, Yu J, Xu Z, Li Q, Yao X, Liu X, Zheng J. Loss of PPM1A expression enhances invasion and the epithelial-to-mesenchymal transition in bladder cancer by activating the TGF-beta/Smad signaling pathway. Oncotarget. 2014; 5(14):5700-5711. DOI: 10.18632/oncotarget.2144 [PubMed: 25026293]

268. Strovel ET, Wu D, Sussman DJ. Protein phosphatase 2Calpha dephosphorylates axin and activates LEF-1-dependent transcription. J Biol Chem. 2000; 275(4):2399-2403. [PubMed: 10644691]

269. Koh CG, Tan EJ, Manser E, Lim L. The p21-activated kinase PAK is negatively regulated by POPX1 and POPX2, a pair of serine/threonine phosphatases of the PP2C family. Curr Biol. 2002; 12(4):317-321. [PubMed: 11864573]

270. Chen MB, Liu YY, Cheng LB, Lu JW, Zeng P, Lu PH. AMPKalpha phosphatase Ppm1E upregulation in human gastric cancer is required for cell proliferation. Oncotarget. $2017 ; 8(19)$ : 31288-31296. DOI: 10.18632/oncotarget.16126 [PubMed: 28423719]

271. Lee-Hoeflich ST, Pham TQ, Dowbenko D, Munroe X, Lee J, Li L, Zhou W, Haverty PM, Pujara K, Stinson J, Chan SM, Eastham-Anderson J, Pandita A, Seshagiri S, Hoeflich KP, Turashvili G, Gelmon KA, Aparicio SA, Davis DP, Sliwkowski MX, Stern HM. PPM1H is a p27 phosphatase implicated in trastuzumab resistance. Cancer Discov. 2011; 1(4):326-337. DOI: 10.1158/2159-8290.CD-11-0062 [PubMed: 22586611]

272. Shen T, Sun C, Zhang Z, Xu N, Duan X, Feng XH, Lin X. Specific control of BMP signaling and mesenchymal differentiation by cytoplasmic phosphatase PPM1H. Cell Res. 2014; 24(6):727741. DOI: 10.1038/cr.2014.48 [PubMed: 24732009]

273. Sugiura T, Noguchi Y, Sakurai K, Hattori C. Protein phosphatase 1H, overexpressed in colon adenocarcinoma, is associated with CSE1L. Cancer Biol Ther. 2008; 7(2):285-292. [PubMed: 18059182]

274. Zhu H, Qin H, Li DM, Liu J, Zhao Q. Effect of PPM1H on malignant phenotype of human pancreatic cancer cells. Oncol Rep. 2016; 36(5):2926-2934. DOI: 10.3892/or.2016.5065 [PubMed: 27599670]

275. Sun T, Fu J, Shen T, Lin X, Liao L, Feng XH, Xu J. The Small C-terminal Domain Phosphatase 1 Inhibits Cancer Cell Migration and Invasion by Dephosphorylating Ser(P)68-Twist1 to Accelerate Twist1 Protein Degradation. J Biol Chem. 2016; 291(22):11518-11528. DOI: 10.1074/jbc.M116.721795 [PubMed: 26975371]

276. Wu Y, Evers BM, Zhou BP. Small C-terminal domain phosphatase enhances snail activity through dephosphorylation. J Biol Chem. 2009; 284(1):640-648. DOI: 10.1074/jbc.M806916200 [PubMed: 19004823] 


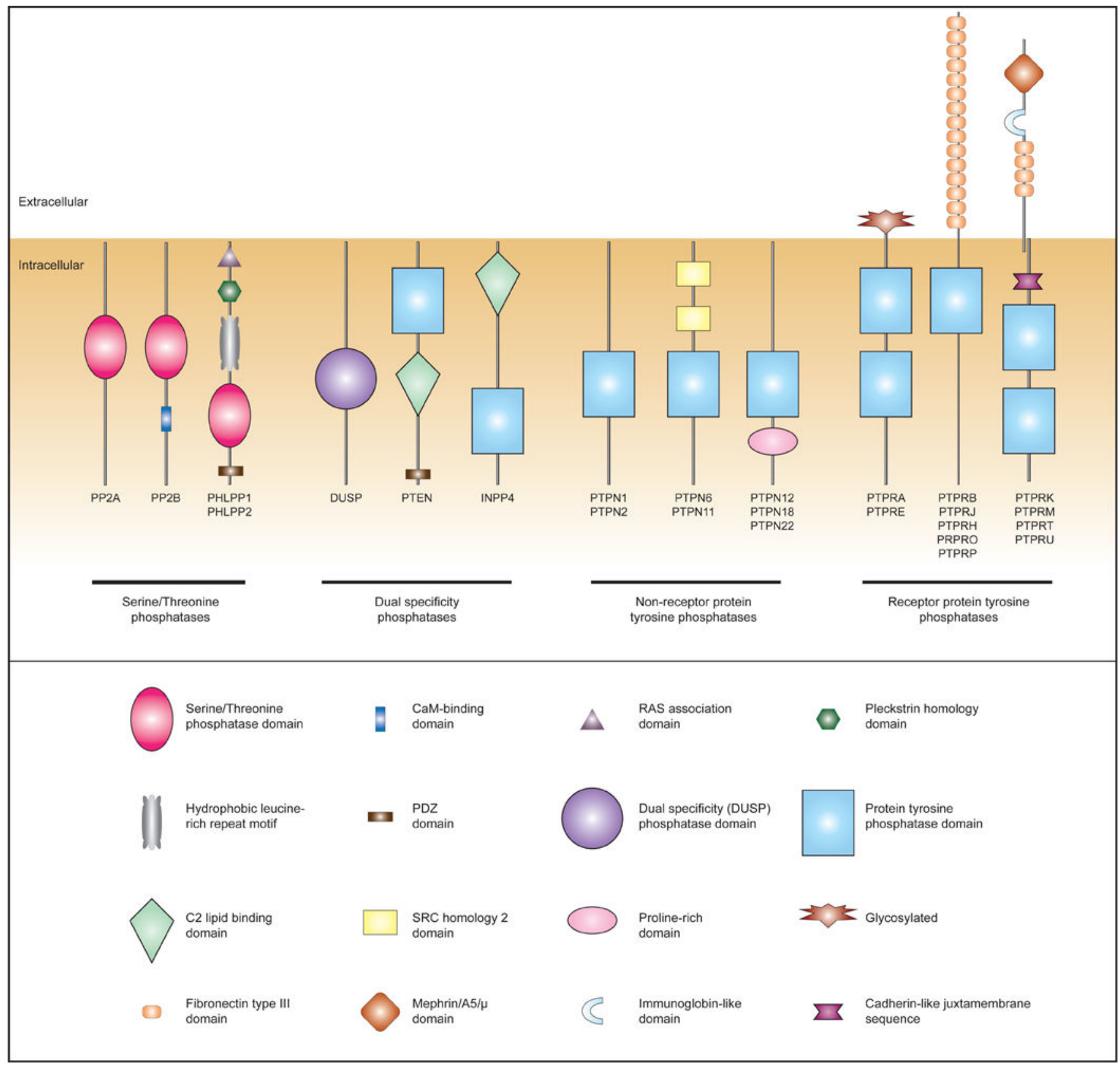

Fig. 1.

Schematic representation of selected serine/threonine phosphatases, dual specificity (DUSP) phosphatases, non-receptor protein tyrosine phosphatases, and receptor tyrosine phosphatases. Several, but not all, important domains are depicted (see the legend at the bottom of the figure). For multi-subunit phosphatases, only the catalytic subunit is depicted. Among PSPs, note the difference in complexity between the catalytic subunits of multimeric PP2A and PP2B and the monomeric PHLPPs. CaM, calmodulin; PDZ, post synaptic density protein 95, discs large homolog 1, zonula occludens-1. 


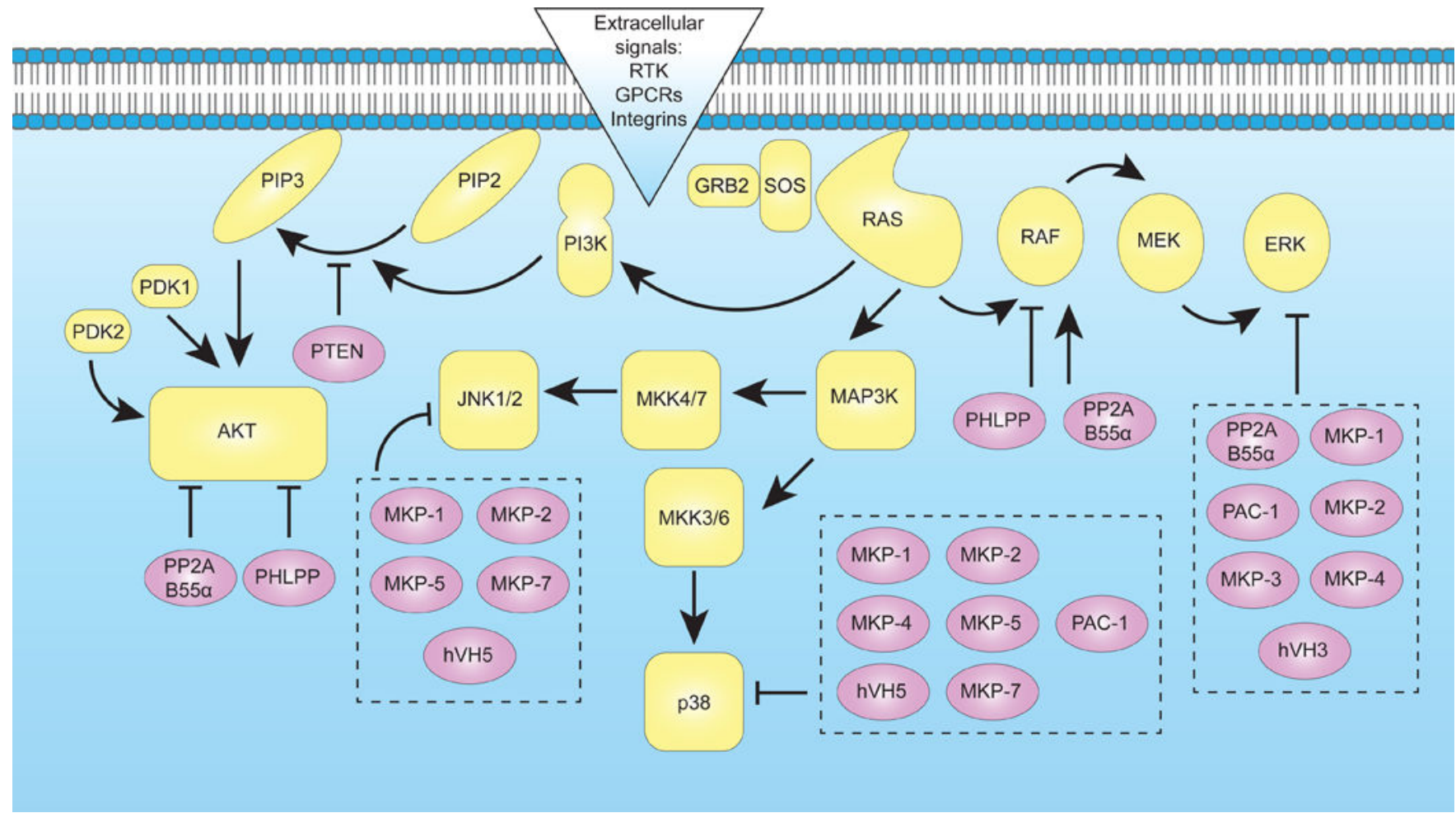

Fig. 2.

Control of the PI3K and RAS signaling pathways by phosphatase signaling. Phosphatases that target components of one or both pathways are shown in violet. Arrows denote activating whereas bar-headed lines denote inhibitory effects. For simplicity, the intervening steps between stimulation of the various receptor types and PI3K/RAS pathway activation are not depicted. See text for further details. GPCR, G protein-coupled receptor; RTK, receptor tyrosine kinase. 

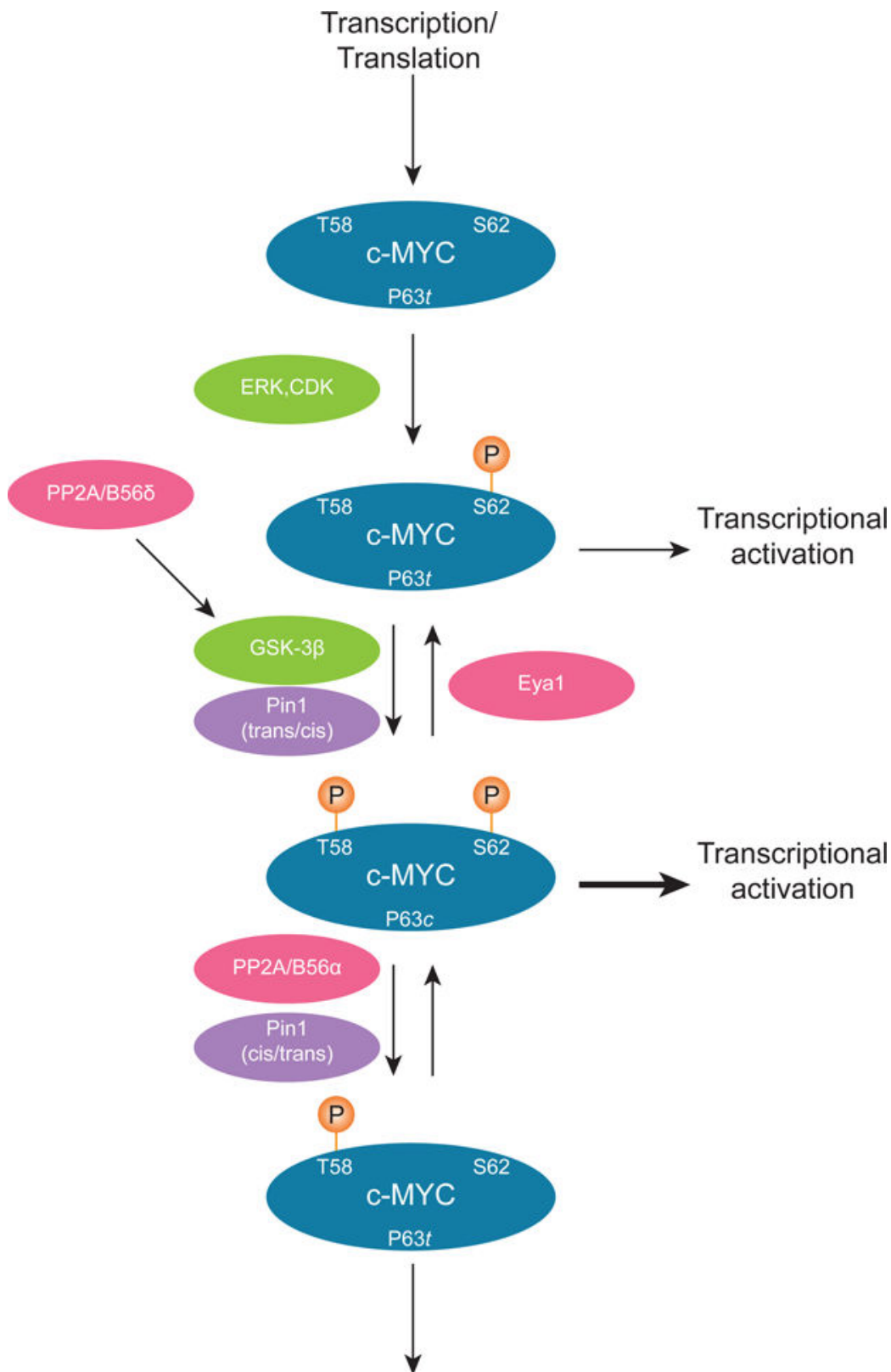

Ubiquitination/

Proteosomal

degradation

Fig. 3.

c-Myc regulation by post-translation modifications. Kinases are shown in green, phosphatases in magenta and the proline isomerase Pin1 is shown in lavender. The c-Myc trans/cis isomerization status at Pro63 is denoted by P63t/c; the two critical phosphorylation sites described in the text are denoted as T(Thr)58 and S(Ser)62. Dephosphorylation of GSK-3 $\beta$ by PP2A-B56 $\delta$ activates the kinase to phosphorylate c-Myc at Thr58. Note the bolder transcriptional activation arrow associated with the doubly phosphorylated c-Myc, as this isoform is thought to have higher transcriptional activity. See text for further details. 


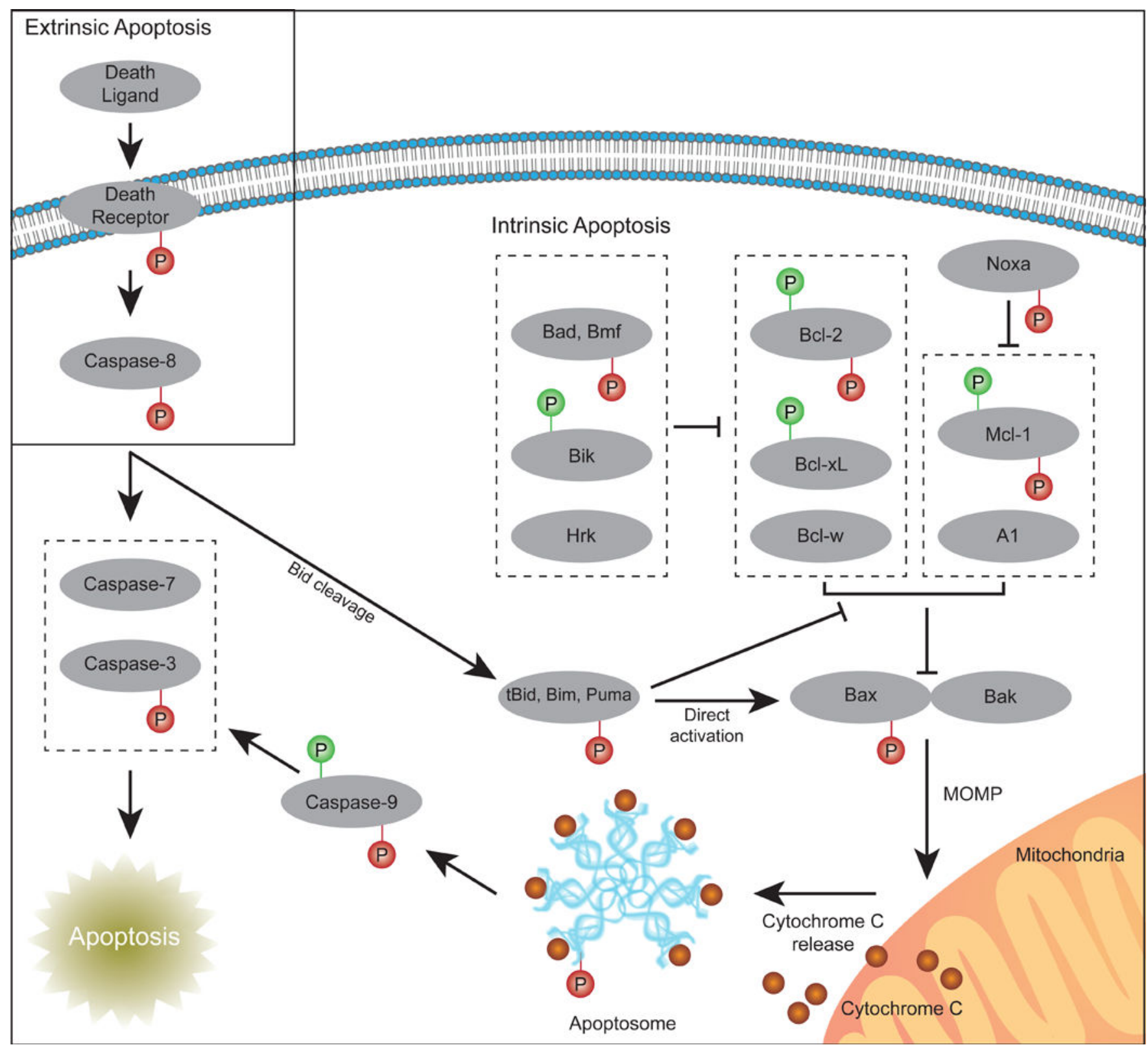

Fig. 4.

Apoptosis signaling pathway and its control by phosphorylation. Phosphorylation events that promote apoptosis are highlighted in green while those that inhibit apoptosis are highlighted in red. Propagation of the apoptotic signal is denoted with an arrow. Inhibitory interactions are denoted with bar-headed lines (for example, t-Bid/BIM/PUMA inhibit the anti-apoptotic $\mathrm{Bcl}-2$ proteins whereas the anti-apoptotic Bcl-2 proteins inhibit Bax/Bak activation). The dotted rectangles represent groups of Bcl-2 family members with differential binding partners (i.e., Noxa preferentially binds to A1 and Mcl-1, whereas Bad/Bik/Bmf/Hrk bind more strongly to $\mathrm{Bcl}-2 / \mathrm{Bcl}-\mathrm{w} / \mathrm{Bcl}-\mathrm{xL})$. See text for further details on the involved kinases and phosphatases. 


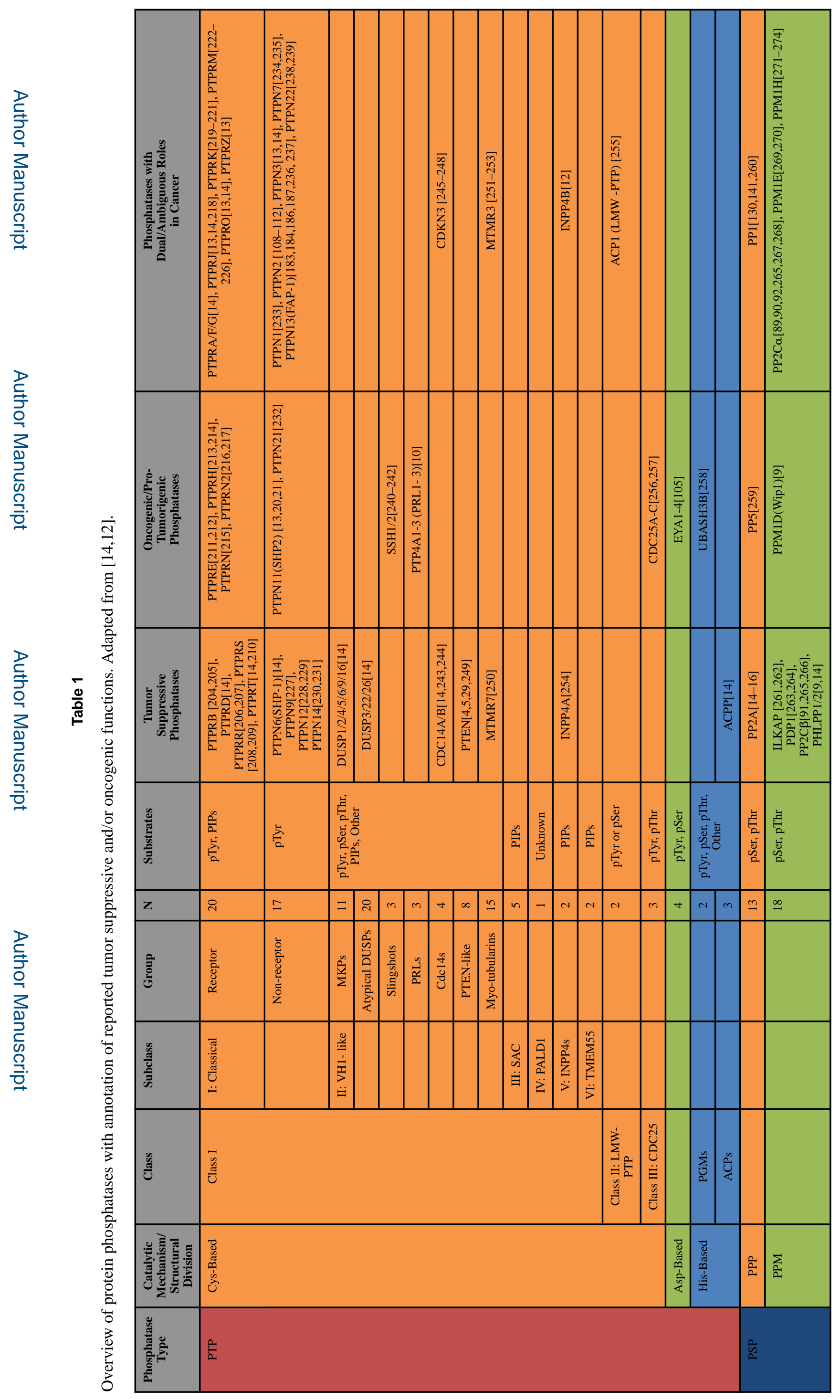




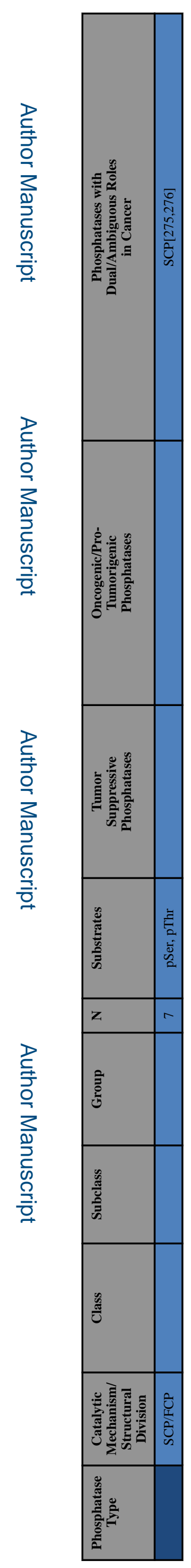

Cell Mol Life Sci. Author manuscript; available in PMC 2019 August 01. 